\title{
Suriyeli Sığınmacılarla Birlikte Yaşama Deneyimi Bağlamında Algı ve Görüşler: Twitter Üzerinden Suriyelilerin Sosyal Temsili
}

\author{
Mustafa Kemal Şan ${ }^{1}$, Engin Durukan Abdulhakimoğulları*2
}

Özet: Bu araştırmanın amacı; Türk toplumunun birlikte yaşama deneyimi bağlamında Suriyelilere yönelik algı ve görüşlerinin hangi konularla ilgili olduğu ve medyada gündem olan konulardan etkilenip etkilenmediğinin belirlenmesidir. Yöntem olarak fenomenolojik araştırma deseninden faydalanılan araştırmanın evreni 16 Ocak 2020 tarihinde "\#Suriyeli" başlık etiketi (Hashtag) ile atılan 6449 tweet ve araştırmanın örneklemi ise analize uygun bulunan 1231 tweet'tir. Söz konusu tarihin seçilme nedeni, "\#Suriyeli" başlık etiketinin Suriyelilere IŞKUUR aracılığıyla iş verilmesiyle ilgili çarpıtılmış bir haber nedeniyle ülke gündemine girmiş olmasıdır. Araştırmadan elde edilen bulgulara göre “\#Suriyeli” başlık etiketi çalışma hakkı ve ekonomiyle ilgili bir nedenden dolayı ülke gündemine girmiş olmasına rağmen Suriyelilere yönelik yorumlarda bir arada yaşamaktan kaynaklı algının birinci, yabancı korkusu ve nefret söylemi ikinci, Suriyelilerin ülkeye kabul edilmesi veya edilmemesiyle ilgili gerekçeler üçüncü, çalışma hakkıyla ilgili yorumların dördüncü sırada yer aldığı görülmüştür. Sonuç olarak, Suriyelilere yönelik algı ve eleştirilerin temel nedeni çalışma hakkı ve ekonomiyle ilgili konulardan ziyade birlikte yaşama deneyimiyle ilgili unsurlardır. Bu da Suriyelilere yönelik algının belirleyicisinin "öteki” olarak konumlandırılmış olmalarından kaynaklandığını göstermektedir.

Anahtar Kelimeler: Birlikte Yaşama Deneyimi, Çalışma Hakkı, Öteki, Suriyeliler, Twitter

\section{Perceptions and Views in the Context of the Experience of Living Together with Syrian Refugees: Social Representation of Syrians on Twitter}

\begin{abstract}
The aim of the research is to indicate, in the context of Turkish society's experience of living together, which subjects are related to the perceptions and views about the Syrians and whether or not it's affected by the current issues. The target population of the research using the phenomenological research design as a method is the 6449 tweets which are tweeted with the Hashtag of "Syrian" on 16th January 2016 and, on the other hand, the research sample is the 1231 tweets which are endorsed to the analysis. The reason for choosing this date is the title tag "\#Syrian" entered the country's agenda with distorted news about employment to the Syrians by İŞKUR. According to the findings obtained from the research, however, the Hashtag "Syrian" entered the country's agenda due to a reason which is about the rights to work and economy in the comments about Syrians. At first, it was seen as a perception stemming from living together ranked, xenophobia and hate speech ranked second, the reasons for the acceptance or rejection of Syrians to the country ranked third, and the comments about the right to work ranked fourth. In conclusion, the main reason for the perceptions and criticisms towards Syrians is the factors related to the experience of living together rather than the right to work and economic issues. This shows that the determiner of the perception towards Syrians stems from the fact that they are positioned as the "other".
\end{abstract}

Keywords: Experience of Living Together, Other, Right to Work, Syrians, Twitter

\footnotetext{
${ }^{1}$ Sakarya Üniversitesi, Sosyoloji Bölümü, Sakarya, Türkiye, mksan@ sakarya.edu.tr, ORCID ID:0000-0002-3669-0766

${ }^{2}$ Jandarma ve Sahil Güvenlik Akademisi, Jandarma Astsubay Meslek Yüksekokulu, Ankara, Türkiye, en.durukan.a@ gmail.com, ORCID ID: 0000-0002-9396-0945

Received: 31 August 2021, Accepted: 22 October 2021, Online: 27 October 2021

* Corresponding Author
} 


\section{Giriş}

Yerküreyi paylaştığımız milyarlarca insan farklı kültürlerin birer temsilcisi olarak varlıklarını sürdürmektedir. Farklı kültürlerden de olsa zorunlu ihtiyaçların temini hususunda bizi diğer insanlardan ayıran hiçbir fark yok gibidir. Herkes yaşamının kaçınılmaz gereksinimlerini karşılamak için yemek yer, elbise giyer, kendilerini doğa olaylarından koruyabilmek amacıyla evler yapar, düşünür fakat kültür, en temel insani ihtiyaçlarımızla ilgili eylemlere müdahale edecek düzeyde kapsayıcıdır. Sorokin'in (1997, s.229) tabiriyle "anlam öğesi olmadan”, kültürel anlam olmaksızın tüm eylemler aynıdır. Yani farklılıkların ve benzerliklerin temeli kültürün alanındadır. Örneğin; insani bir ihtiyaç olarak beslenmek önemlidir fakat neleri yiyeceğimizi ve nasıl yiyeceğimizi belirleyen temel yapıtaşı kültürdür. Kıyafetler önemlidir fakat kıyafetlerin nasıl olacağını belirleyen şey kültürdür. Doğal bir vasfımız olarak düşünme yetimiz önemlidir fakat sosyal ilişkiler bakımından önemli olan, konular hakkında nasıl düşündüğümüzdür; düşünce farklılıkları nedeniyle tarih boyunca savaşların, çatışmaların, ayrılıkların yaşandığına sıkça şahit olmaktayız. Nihayetinde her insan için aynı olan temel ihtiyaçlarımız ve eylemlerimiz sosyo-kültürel yapı çerçevesinde farklılaşmakta ve bizim gibi olanlar ile bizim gibi olmayanlar yani bizler ve ötekiler ayrımına neden olmaktadir.

Mlodinow (2013, s.194-197), çevremizi kuşatan her şey için birtakım özelliklerine göre sınıflandırmalar yaptığımızı ve bu sınıflandırmaların doğal olduğunu sosyo-psikolojik deneylerden örneklerle izah etmiştir fakat sorun sınıflandırdığımız şeyleri aynı zamanda kutuplaştırma ihtimalimizdir. Aynı sınıfa dahil ettiğimiz şeyler, aslında olduğundan daha benzer gibi algılanırken, diğer gruplar içinde sınıflandırılan şeyler ise olduklarından daha farklı algılanabilmektedir. Örneğin Mbembe (2019), siyahilere yönelik ayrımın tarihsel süreç içinde nasıl inşa edildiğini anlattığı "Zenci Aklın Eleştirisi”" adlı kitabında, farklılıkların neden olduğu dışlanma ve ayrımcılık biçimlerinin tek boyutlu olmadığını siyahilerin yaşadığı deneyimler üzerinden açıklamaktadır. Siyahilere yönelik ayrımcılığın yalnızca ten renklerinin farklı olmasından kaynaklanmadığını, aynı zamanda ekonomiyle, dinle, siyasetle ve kültürle ilgili daha birçok ayrım türünü de ihtiva ettiğini göstermektedir.

Günümüzde ekonomik zorluklar, sosyal sorunlar, siyasi çatışmalar ve kıtlık gibi nedenlerden dolayı insanlar daha iyi yaşam koşullarına sahip olmak veya canlarını kurtarmak amacıyla başka ülkelere göç etmektedirler. Bu durum kadim bir geçmişi olan göç olgusunu ülkeler açısından hem firsat hem de bir sorun haline getirmektedir. Yetişmiş insan kaynağı ve emek gücüne duyulan ihtiyaç bakımından göçler bir fırsat olarak görülmekle birlikte ev sahibi toplumda sosyal değişmelere neden olması bakımından tehdit 
olarak algılanması da mümkündür. Göçün nasıl bir etki yaratacağı ise göçün türü, göç edenlerin etnik, dini ve ulusal kimliği, göç edilen yerin sosyo-ekonomik yapısı, ev sahibi toplumun dahil etme kapasite ve becerisi, göçmen politikaları önemli hususlardır. Özellikle kendi ülkelerindeki siyasi, ekonomik ve sosyal nedenlerden dolayı başka ülkelere sığınan mülteciler, kaçak göçmenler yerleştikleri ülkenin güvenliği ve toplum yapısı üzerine olası olumsuz etkileri nedeniyle en istenmeyen göçmen grupları olduğu söylenebilir.

Suriye'de çıkan iç savaş sonrasında Türkiye'ye sı̆̆ınan Suriyeliler için de durum yukarıda ifade edildiği gibidir. Başlangıçta toplum tarafından“misafir” olarak kabul edilen Suriyeliler, ülkelerine dönmek için gerekli koşulların oluşmaması nedeniyle Türk toplumuna dahil olarak burada kendilerine yeni bir düzen kurmaya başladılar. Bu doğrultuda yaklaşık 10 yıldır Suriyelilerle birlikte yaşama deneyimi edinmiş olan Türk vatandaşlarının, toplumsal yaşamın birçok farklı boyutu açısından Suriyeler hakkında görüşlere sahip olması kaçınılmazdır. Suriyeliler ve yerel halk arasında farklılıkların nasıl algılandığı göçmenlerin uyumu ve yerel halkın göçmenleri kabulü bakımından önem taşımaktadır. Bir arada yaşama deneyimi çerçevesinde araştırmanın amacı Suriyeli sı̆̆ınmacılara yönelik algı ve görüşlerin daha çok hangi konularla ilgili olduğunun belirlenmesidir. Araştırma kapsamında öncelikle “öteki” olgusu ve öteki olgusuyla ilişkili kavramlar değerlendirilmiştir. Daha sonra Twitter'dan çekilen veriler 1şı̆̆ında araştırmanın bulgularına değinilecektir.

\section{2. Öteki Olgusu ve Ötekiyle İlgili Temel Kavramlar}

\section{1 İç Grup-Dış Grup Bağlamında Öteki}

Tarih boyunca insanlar kendilerinden farklı inanca, dile, dine, kültüre sahip insanlarla yani kendilerinden olmayan "öteki” ile etkileşim halinde olmuşlardır. Dolayısıyla ötekinin varlığı doğal bir durumdur ve insanlığın kültürel zenginliğinin kaynağıdır. Ötekinin varlığı hem maddi hem de manevi ögelerde karşımıza çıkmaktadır. Onların bizden farklı olan yönlerini toplumsal yaşantımızda maddi unsurlar aracılığıyla fark edebildiğimiz gibi düşünsel boyutta da ötekinin bizden farklı olduğunu hissederiz. Gasset'e göre (2011, s.107) insanlar kendi varlıklarının farkına vardıkları andan itibaren öteki konumundaki insanların arasında onlarla iç içe bir haldedir. Dolayısıyla ilk “öteki” "ben” olmayan insanlardır. Öteki hakkındaki bu görüş, onun varlığını sosyal ilişkilerin doğal bir unsuru olduğunu göstermektedir. Burada temel sorun ötekinin varlığının normal bir durum olmaktan çıkıp bir arada yaşanmak istenmeyen, tehdit olarak algılanan, nefret ve düşmanlık beslenen bir duruma gelmesidir. 
Biz ve ötekiler ayrımını Bauman (Bauman, 2006, s.51-53) biz "iç grup” ve ötekiler "dış grup" bağlamında değerlendirmiştir. İç grup (biz), karşılıklı ilişkilerin nasıl sürdürüleceği belli, kendimizi aralarında güvende hissettiğimiz yani aidiyet hissimizin olduğu gruptur. Dış grup (ötekiler) ise üyesi olunmak istenmeyen, kendimizi aralarında güvende hissetmediğimiz, iletişime geçmekten kaçındığımız ve hatta korkutucu bulduğumuz gruptur.

İç grup, grup üyelerini kapsayan homojen kimlik ve aidiyet duygusunu barındırır. Benzer durum diş grup için de geçerlidir. Öteki yani dış grupta yer alan üyeler de homojen bir kimliğe ve aidiyet duygusuna sahiptirler. Dolayısıyla iç ve dış gruptan bahsedebilmek için zıtlıkların varlığı ve bu zıtlıkları oluşturan unsurları temsil eden insan gruplarının varlığı gereklidir. Fakat her farklılık bir öteki yaratmamaktadır. Belirli bir grubun dış grup olarak ötekileştirilmesi için çıkar çatışması, coğrafi yakınlık ve/veya tarihsel temasın bulunması gerekmektedir (Kırıkçı, 2017, s.381).

İç grup/dış grup ayrımının nasıl oluştuğunun anlaşılması bakımından Sherif'in (1988) "Soyguncular Mağarası Deneyi” (Robbers Cave Experiment) adlı araştırması önemlidir ${ }^{1}$. Farklı iki grup karşılaştığında eğer çıkar çatışması varsa neler olabileceğini araştırmıştır. Yapılan sosyal deney sonucunda iç ve diş gruplar arasında çıkar çatışmaları nedeniyle düşmanlığın, dış gruba yönelik önyargı ve ayrımcılı̆̆ın oluştuğu gözlemlenmiştir. Doğaları bakımından aralarında fark bulunmayan çocuklar bile farklılaşma ve ayrışma imgeleri sonucu kendi gruplarına dahil olmayanları ötekileştirmektedir. Ötekileştirme imgeleri yargı içeren bir takım kalıp yargılar, önyargılar, stereotipiler ve damga şeklinde vuku bulan bir düşünce ve algı biçimine neden olmaktadır (Nahya, 2011, s.30). Tabii ki ötekileştirme tek yönlü bir süreç değildir. Aksine bu süreç karşılıklı bir tepkinin ürünü de olabilmektedir. Bu nedenle biz ve öteki karş1lıklı olarak ortak bir tarihsel arka plana bağlıdırlar (Kierkegaard, 2013, s.21) ve ötekinin varlığı toplumsal yaşamın her alanında görünür haldedir. Örneğin şehirler, ülkeler, cinsiyetler, meslek grupları, göçmenler çıkar çatışmaları veya rekabet nedeniyle birbirlerini ötekileştirilebilirler.

Bilgin'e göre (2007, s.180) ötekileştirmeye neden olan gruplar arasında etkileşimin kısıtlı veya hiç olmadığı durumlarda ötekileştirilen grupların doğru anlaşılması daha da zorlaşacaktır. Ayrıca öteki hakkında bilgi edinmek için ötekinin nasıl temsil edildiğine bakılması yeterli değildir. Ötekinin nasıl temsil edildiğine bakarak temsilin sahibi hakkında bilgi edinmemiz de gereklidir. Bu doğrultuda ötekileştirmenin,

${ }^{1} 1954$ yılında gerçekleştirilen deneyde 22 kişiden oluşan bir grup erkek çocuk iki gruba ayırtılarak kamp yapmaya götürülmüşlerdir. Çocuklardan hiçbiri bir deneyin parçası olduklarının farkında değildir. Eğitim ve sosyal çevreleri açısından birbirlerine çok benzer olan bu çocuklar kamp yerlerinde diğer gruptan haberleri olmadan bir müddet kendi aralarında vakit geçirmişlerdir. Bu süreç içinde iki grup da kendi bayraklarını, marşlarını, gruplarının isimlerini, kıyafetlerini ve grup içi kurallarını belirlemistir. Grup içi bütünleşme sağlandıktan sonra birbirinden habersiz olan iki grup tanıştırılarak ikinci aşamaya geçilmiştir. Bu aşamada iki grup arasında kazanana ödül verilen fakat kaybedene herhangi bir ödülün verilmediği spor yarışları düzenlenmiştir. İki grup arasındaki çekişme nedeniyle kısa sürede önyargılar ve karşılıklı olarak birbirlerinin eşyalarına zarar verme olayları yaşanmıştır. Çocuklara kendi gruplarını ve diğer grupları değerlendirmeleri istendiğinde ise çocuklar iç grubu olumlu ve dış grubu olumsuz ifadelerle değerlendirmişlerdir. 
yani ötekilere olumsuz anlam ve imgeler atfedilmenin 4 farklı işlevi bulunmaktadır ${ }^{2}$ (Bilgin, 2007, s.180):

- Kimlik inşası işlevi

- Yansıtmayla rahatlama ya da kimlik yüceltme işlevi

- Meşruluk sağlama işlevi

- Sosyal düzeni koruma işlevi

Ötekileştirmenin ilk işlevi olan “Kimliğin inşası işlevi”, ötekileştirilenin zorunlu olarak biz karşısında alçaltılmasını, "biz"in ise yüceltilmesiyle ilgilidir (Bilgin, 2007, s.179). Bizi tanımlayan ve ötekilerden ayrılmamızı sağlayan unsur kimliktir. Kimliğin birçok çeşidinin olması ve yaşantımızı parçalara ayırması nedeniyle Baudrillard'a göre (2015, s.55) kimlik, ötekilik simülarkına neden olmaktadır. Huntington'ın (2004, s.21) "belirsiz, bir o kadar da kaçınılmaz" olarak gördüğü ve bu yüzden tanımlamasının zor olduğunu belirttiği kimlik en yalın haliyle "kişilerin, grupların ve toplulukların "Kimsiniz, kimlerdensiniz?" sorusuna verdikleri yanıt ya da yanıtlardır" (Güvenç, 1995, s.3). Ben/biz ve öteki arasındaki ayrım kimliklerin farklılığı üzerinden vurgulanmaktadır (Keyman, 1996, s.78). Bu yönüyle kimlik ve öteki arasında diyalektik bir ilişkinin olduğunu söylemek mümkündür. Kimlik bu ilişki içinde farklılığı oluştururken, ötekilik ise kimliğe güven kazandırmaktadır (Connolly, 1995, s.24). "Yansıtmayla rahatlama ya da kimlik yüceltme işlevi”, ötekileştirilen grupta görmek istediğimiz özelliklerle ilgilidir. Bu işlev açısından öteki ile değer yargılarımızın uyuşup uyuşmamasına göre “iyi” veya "kötü” olarak yargılanarak ötekinin kimliği hakkında genel bilgiler oluşturulur (Bilgin, 2007, s.180) Dolayısıyla "biz" ve "öteki" ayrımının temelinde yer alan unsur zıtlıklardır. "Diğeri, öteki, yabancı, başkası” olarak çeşitli şekillerde ifade edilen, "bizden olmayanlar" yani bizden farklı olanlara atfedilen bir özelliktir. Bu yönüyle öteki “benzer-farklı, yerli-yabancı, yakın-uzak, dost-düşman, normal-sapkın, azınlık-çoğunluk” gibi diyalektik ilişkilerle tanımlanmaktadır" (Bilgin, 2007, s.176-177).

“Meşruluk să̆lama işlevi”, ötekinin kimliğinin meşruluk kazandırılmasıdır. Ötekinin meşruluğu sağlanarak iç grubun kimliği meşrulaştırılmış olunacaktır. "Sosyal düzeni koruma işlevi” ise mevcut düzenin korunması amaçlanır. Bu bakımdan öteki bir günah keçisidir ve iç grup içinde mevcut düzenin garantisi ötekinin her zaman öteki olarak varlığını sürdürmesine bağlıdır (Bilgin, 2007, s.187-188). Ötekileştirilen grubun varlığı iç grubun düzeninin sürekli yeniden üretilmesini sağlayan bir unsurdur. Öteki

\footnotetext{
${ }^{2}$ Keyman (Keyman, 1996, s.76-78) ötekine karşı oluşturulan genel ve egemen söylemleri beş farklı yaklaşıma göre tasnif etmiştir. Buna göre ötekileştirme söylemleri “ampirik bir nesne olarak öteki", "kültürel bir nesne olarak öteki", "bir varlık olarak öteki”, "söylemsel bir yapı olarak öteki" ve "farklılık olarak öteki" şeklinde gerçekleşmektedir.
} 
bu rolüyle düzen bozan, gelenekleri tahrip eden, toplumsal normların içini boşaltan tehlikeli olanlardır (İnce, 2011, s.182). Yani günah keçisi olarak ötekiler tüm talihsizliklerimizin sorumlularıdırlar (Allport, 2016, s.288). Schnapper'a göre (2005, s.137) ötekileştirilen grupların günah keçisi ilan edilmesi, bireylerin ve grupların kendi iç çatışmalarını çözmesini sağlayarak grup içi kaynaşmaya katkı sağlamaktadır.

Ötekileştirilen gruplar iç ötekiler ve dış ötekiler olarak ikiye ayrılmaktadır. Bu ayrım günümüz ulus devletlerinin egemen kimliğinin inşasından kaynaklanmaktadır. İç öteki, ülke sınırları içinde yer alan azınlık konumunda bulunanlardır. Azınlıklar toplum içinde farklı ve marjinal algılandıkları için ötekileştirilirler (Gölcü, Dağl1, 2017, s.16). Bu nedenle bir arada yaşama konusunda iç ötekiler bir sorun olarak görülmektedir. Schnapper'a göre (1995) ulus devletlerde özel yaşamın çokkültürlü yapısı genel olarak kamusal yaşamın birlik, eşitlik ve evrensellik ilkesiyle ters düşmediği sürece sorun değildir. Bir ideal biçim olarak ulus devletlerde kültürel, dini ve etnik farklılıklarına bakılmaksızın tüm yurttaşların ülkenin yasalarına uymaları beklenir. Tarihsel ve siyasi bir proje olan ulus devletler iç bütünleşmeyi sağlaması gerekmektedir. İç bütünleşmenin önündeki engel azınlıklardır. İç bütünleşmenin sağlanması için devletin elindeki en önemli ideolojik aygıt eğitim ve tarihtir. Bu noktada dış etkinlikler de gereklidir yani ötekileştirilen devletler.

Ötekileştirilen bir diğer dış grup ise geldikleri topluma yabancı olan göçmenlerdir. Kaya’ ya göre (2015, s.49) dış ötekiler olarak yabancılar ve etnik gruplar, göçmenler birer tehdit olarak algılanmakta ve ülke içinde yer alan ötekiler sıkça suç unsurları ile anılarak ötekileştirilmektedir. Fakat ülkeye göç eden herkes toplum için bir tehdit unsuru olarak kabul edilmemektedir. Göçün bir ötekileştirme unsuru haline gelmesi göçün türü ve kimlerin (etnik kimlik, ulus kimliği) göç ettiğiyle ilgilidir. Genel olarak kaçak göçmenler, mülteci ve sığınmacılar ötekileştirmeye maruz kalan gruplardır (Aydın, Oğuz, 2015, s.303). Fakat kitlesel göçlerde, ülke bu göçlere ihtiyaç duysa dahi yerel halkın göçmenlere karşı ayrımcı tutumlarda bulunması, göçmenlerin ötekileştirilmesi sıklıkla tanık olunan bir durumdur. Örneğin Almanya emek arzına ihtiyaç duyduğu için Türkiye ile işçi göçü konusunda 1961 yılında ikili anlaşmalar yapmıştır. Türkler kitleler halinde Almanya’ya göç etmiş ve çalışma hayatında kendilerine yer edinmişlerdir. Antlaşmaya bağlı olarak çalışma hayatına kabul edilen Türkler yine de ötekileştirmeye maruz kalmaktan kurtulamamışlardır. Bunun nedeni, Almanya’ya göç eden Türklerin farklı bir etnik ve ulus kimliğine mensup olmaları, dolayısıyla Alman halkından farklı bir kültürel gruba mensup olmalarıdır. Fakat buradan yerel halkın tamamının göçmenleri ötekileştirdiği, ayrımcı tutum sergilediği anlamı çıkarılmamalıdır. Göçmenlere yönelik tutumlar ötekileştirici olabileceği gibi göçmenleri dost, mă̆dur ve yardıma muhtaç insanlar olarak algılayan veya ülkenin kalkınması için yeni bir fırsat olarak düşünenlerin olması da mümkündür. 
Göçmenlerle yerel halk arasında din, dil, kültürel pratikler gibi unsurlarla ortaya çıkan ve hemen hissedilen farklılıklar bulunmaktadır (Castles, Miller, 2008, s. 18). Karşılıklı olarak hem göçmenler hem de yerel halk birbirine yabancı olması ve dil bilmeme nedeniyle birlikte yaşama konunda potansiyel endişeleri barındırmaktadır. Genelde göçmenlerin bu konudaki endişe ve kaygıları üzerine durulmaz. Çünkü ister zorunlu nedenlerden yahut gönüllü olarak gelmiş olsunlar, sonradan gelenler oldukları için hak talebinde bulunmaları pek mümkün değildir. Norbert Elias’ın bu konuda öne sürdüğü “yerleşikler ve dışardakiler" teorisine göre dışarıdan gelenler yerleşiklerin yaşam tarzlarına kafa tutmaktadırlar. Yerleşiklerin yeni gelenlere yer açma zorunluluğu bulunmaktadır. Bu nedenle dışarıdan gelenlerle aradaki farklılıklar abartılır, bu insanlar tiksinti duyulan, endişe ve düşmanca yaklaşılan bir konuma gelirler (Bauman, 2006, s.60).

Bauman'1n görüşleri yabancılar sorununa 1şık tutmaktadır. Bauman'a göre (2003, s.74-83); “Dostlar ve düşmanlar vardır, bir de yabancılar vardır”. Yabancılar toplumsal yaşamın varlığını tehdit ettikleri için düşmanlara göre daha belirsiz ve korkutucudurlar. Dost ve düşmanların konumu belirlidir fakat yabancıların konumu müphemdir. Ne dost ne de düşmandırlar. Her ikisi de olma ihtimalini barındırırlar. Dolayısıyla yabancı, “yakınlık ve uzaklık sentezi”ni temsil etmektedirler.

Yabancılara en iyi örneklerden biri sı̆̆ınmacı ve mültecilerdir. Davet edilmedikleri ve istenmedikleri halde yeni yerlerine gelmiş ve yerleşiklerin arasına karışmışlardır. Bauman'a göre (2006, s.71) “Onlar yeni gelenlerdir; bizim hayat tarzımız onlar için yenidir, bizim usullerimizi ve araçlarımızı bilmezler. Bu yüzden, bizim için normal ve doğal olan, bizim hayat tarzımızdan "doğmuş" olan ne varsa onlar için tuhaf ve bazen de şaşırtıcıdır.” Yerleşikler için varlıkları huzur bozucudur ve güvenlik sorunu olarak görülürler. Potansiyel bir tehlike unsurudurlar ve bu nedenle yabancı düşmanlı̆̆ 1 (Xenophobia) giderek artar. Yerleşiklerin verdiği ilk tepki Bauman’a göre (2006, s.73-74) “geldikleri yere” göndermektir. Bunun mümkün olmadığı durumda soykırım da ihtimaller arasındadır. Daha az nefret içerikli tepki ise ayrılmaktır. $\mathrm{Bu}$ ayrılık hem maddi (örneğin gettolar) hem de manevi (sosyal mesafe) şeklinde gerçekleşebilir. Manevi mesafe maddi mesafenin gerçekleşmediği veya mümkün olmadığı durumlarda ortaya çıkmaktadır. Böyle durumlarda yerleşiklerle yabancılar arasındaki ilişki iş ilişkisi düzeyindedir. Yabancıların bulaşıcı hastalıklar yayacağından, pis olduklarından, zararlı fikirler ve düşüncelere sahip olmalarından endişelenilir Yabancılarla maddi ayrılığın gerçekleşmediği durumlarda aynı sosyal alan içinde yaşanılmaktadır. Fakat yabancılar bir komşu mesafesi kadar yakın dahi olsalar bile komşu değildirler. Kendileriyle hiç karşılaşılmak istenmez ve eğer karşılaşmamak mümkün değilse sahte karşılaşmalar tercih edilir. Bu karşılaşma türünde yabancılar görmezden gelinir (Bauman, 2011, s.188). Bu durum birlikte yaşama kültürünün oluşmasının önündeki önemli engellerden biridir. Göçmenlerle bir arada yaşama deneyimi açısından toplumsal yaşamın her alanında sorunların ortaya çıkması mümkündür. Her şeyden önce de belirtildiği gibi yeni gelenlere 
yer açılması gereklidir (Bauman, 2006, s.60). Fakat yeni gelenlere yer açılmasıyla sorunların giderek çeşitlenme olasılı̆̆ yüksektir.

\subsection{Nefret Söylemi}

Göçmenlere ve genel olarak öteki olarak kabul edilen gruplara karşı hem eylemleri hem de algıları etkileyen en önemli hususlardan biri nefret söylemidir. Nefret söylemi, 1997 yılında Avrupa Konseyi Bakanlar Komitesi’nin kararıyla şu şekilde tanımlanmaktadır: "Nefret söylemi kavramı, ırkçı nefreti, yabancı düşmanlığını, Yahudi düşmanlığını veya azınlıklara, göçmen kökenli insanlara yönelik saldırgan ulusalcılık ve etnik merkezcilik, ayrımcılık ve düşmanlık şeklinde ifadesini bulan, dinsel hoşgörüsüzlük dâhil olmak üzere hoşgörüsüzlüğe dayalı başka nefret biçimlerini yayan, kışkırtan, teşvik eden veya meşrulaştıran her türlü ifade biçimidir” (Weber, 2009, s.3). Göçmenler ve yabancilar geldikleri yerin yerleşiklerinden farklı bir etnik kimliğe ve kültüre sahip olmaları nedeniyle nefret söyleminin ihtiva ettiği çoğu unsura maruz kalmaktadırlar.

İç ve dış ötekiler veya göçmenlerin ötekileştirilmesinde temel unsurlardan biri önyargılardır. Göçmenlerle yerel halkın arasına katılmasıyla birlikte ekonomik, siyasi, çalışma hakkı ve güvenlik gibi konularda ortaya çıkan sorunlar veya kaygılar ötekine yönelik nefret söylemleri, etnik merkezcilik, yabancı düşmanlığı, ırkçılık ve yeni önyargıların, kültürel farklılıklardan kaynaklı yanlış yargıların ortaya çıkmasına neden olmaktadır (Tekeli, 1998, s.87). Yerel halkın kültürü ile yeni gelenlerin kültürlerinin farklı olmasından dolayı iki grup arasındaki iletişim kültürlerarası iletişim bağlamında değerlendirilmesi gerekmektedir. Fakat nefret söylemleri, etnik merkezcilik, yabancı düşmanlığı ve ırkçılık gibi ayrımcı unsurlar yerel halk ile göçmenler arasında iletişimin kurulması önünde engel olmaktadır. Nitekim iletişimin kurulmasıyla birlikte ötekine yönelik bu tür ayrımcı unsurlar yerini empati ve sempati söylemlerine ve birlikte yaşama hususunda daha olumlu yaklaşmalarına olanak sağlamaktadır.

Etnik merkezcilik, bireylerin kendi kültürlerini ve etnik kimliklerini merkeze alarak farklı kültürleri değerlendirmesidir. Bu bakımdan etnik merkezcilik öteki etnik kimliklere ve kültürlerini alçaltırken bireylerin kendi kültürlerini ve etnik kimliklerini yüceltmeleri anlamına gelmektedir (Uzunçarşılı Soydaş, 2010, s.138). Etnik merkezci söylemlerde ötekileştirilenlerin etnik ve kültürel kimliklere karş1 nefret söylemleri kullanılarak hor görülür ve aşağılanır. Böyle durumlarda bireyler kendi etnik kimliklerini ve kültürlerinin ise üstünlüğünü dile getirirler. Örneğin, “Bir Türk dünyaya bedeldir.”, “Türkün Türk’ten başka dostu yoktur.” gibi söylemler etnik merkezci söylemlerdir. Öz itibariyle bu tür söylemler irkçı ve ayrımcı söylemler de içerebilmektedir. 
Göçmen karşıtı söylemlerde sıkça görülen özelliklerden biri de göçmenlerin ülkede suç artışlarına, toplumsal düzenin bozulmasına, güvenliğin azalmasına vb. neden olacakları yönündeki endişedir. Bu tür endişelerin kaynağı yabancı korkusu ve düşmanlığıdır. Bauman’a göre yabancı olan herkese karşı duyulan korkunun, düşmanlığın ana kaynağı önyargılardır. Yabancının kıskançlıkla kollanmasına, ona karşı güvensizlik duygusuna, toplumsal düzenin kaybolması nedeniyle duyulan bir kine neden olmaktadır (Bauman, 2006, s.59-60). Van der Veer arkadaşları (2013) Hollanda, Amerika ve Norveç’te yaptıkları araştırma sonucu yabancı düşmanlığı üzerine geliştirdikleri ölçekte yabancı düşmanlığının kişisel korku, kültürel değişim korkusu, kimlik kaybı, sadakatsizlik korkusu ve siyasi korkudan oluştuğunu belirtmişlerdir.

\section{3 Ötekine Karşı Hoşgörünün Kaynağı: Empati ve Sempati}

Göçmenler geldikleri yerin yabancıları olarak görülmekle birlikte bazı insanlar göçmenlere hoşgörüyle yaklaşarak etkileşime girebilirler. Göçmenlere yönelik hoşgörü, onları görmezlikten gelmek veya Bauman'ın ifade ettiği şekliyle sahte karşılaşmalardan ziyade etkileşim sürecinde kültürel farklılıkların farkında olunmasını gerekli kılmaktadır. Özellikle geldikleri topluma yabancı olan göçmenlerin geldikleri yerin toplumsal yapısına entegre olmaları için yerel halk tarafından hoşgörüyle karşılanmaları önemli bir durumdur. Hoşgörü, dış grubun dilinin, dini inancının, kültürünün, ırkının, etnik kimliğinin ve diğer kimliklerinin varlığından rahatsız olmamayı, bu farklılıkları reddetmemeyi ve görmemezlikten gelmemeyi, aksine bu farklılıkların farkında olmayı gerektirmektedir. Bu bağlamda hoşgörülü bireylerde bulunan temel unsurlar şöyledir: dış grubun taşıdığı farklılıklarına önem verir, dış grubu ve farklılıklarını onaylar, onlarla barış ve iyilik içinde yaşar, dış grubun farklı anlayış, düşünce ve inançlarını reddetmez, onu tabii çerçevesinde kabul eder, dış gruba farklılıkları deneniyle ayrımcı davranmaz. Fakat hoşgörülen iç grubun kültürel doğasına aykırı olmaması beklenir (Aslan, 2001, s.373).

Hoşgörüyle ilişkili olarak bir diğer unsur empati ve sempatidir. Bu iki kavram çoğu zaman birbiri yerine aynı anlamda kullanılmaktadır. Aslında günümüzde empati kelimesiyle anlatılmak istenen 18. yüzyılda sempati kelimesiyle ifade ediliyordu. Günümüzde empati kelimesiyle "insanların kendi aralarındaki duygusal etkileşimi anlatmak", "o kişiyi yabancılaştırmak yerine yakın hissettirecek şekilde tepki verebilmek" gibi duygular ifade edilmektedir (Watt-Smith, 2019, s.78-79). Sosyolojik anlamda empati ise "toplumsal, kültürel, sosyal anlamda alt kültür grubunda bunulan insanların benzerliklerini kabul edip onlarla iletişim kurmayı başarmasıdır." Sempati ise "bir insanın karşısındakinin duygularına aynı şekilde katılması" anlamına gelmektedir (Tarhan, 2013, s.162).

Hoşgörü, sempati ve empati gibi kavramlar, farklılıkların bir arada yaşaması hususunda kültürlerarası 
iletişimin başarısını mümkün kılacak unsurlardır. Kurulacak olan kültürlerarası iletişimin başarılı olabilmesi kültürel farklılıkların farkında olunmasını gerekli kılmaktadır. Bu durum, kültürlerarası iletişim yeterliliğinin bir unsuru olan kültürlerarası duyarlılık kavramıyla ifade edilmektedir. Kültürlerarası duyarlılık, farklı kültürlerden insanlarla iletişime girildiğinde, onların değer, norm ve davranışlarının farklılıklarına saygı göstermek anlamındadır. Ayrıca söz konusu farklılıklara saygı duyulması kültürlerarası duyarlılığa sahip olmanın bir gereğidir (Bhawuk ve Brislik, 1992, s.414-416).

Göçmenlere yönelik nefret söylemi, etnik merkezcilik, yabancı korkusu gibi unsurlar toplumsal kabulü ve göçmenlerin geldikleri yere uyumunu olumsuz yönde etkileme ihtimali bulunmaktayken hoşgörüye dayalı empati, sempati ve kültürlerarası duyarlılığın olması ise toplumsal kabulü ve göçmenlerin uyumunu olumlu yönde etkileme ihtimali nedeniyle göz önünde bulundurulması gerekilen önemli hususlardır.

\section{Sosyal Medya Üzerinden Suriyeli Algısı Araştırmaları Literatürü}

Sosyal medya siteleri üzerinden yapılan çalışmalar gün geçtikçe artmaktadır. Sosyal medya kullanıcıları farklı birçok konu hakkında sundukları görüşler sosyal bilimlerde farklı konuların araştırılmasında veri olarak kullanılmaktadır. Öyle ki İslamafobi, borsa, tüketici tercihleri, siyasi konularda duygu analizi, kurum veya olguların nasıl algılandığı gibi farklı konular için sosyal medya siteleri uygun veriler sunabilmektedir. Mevcut literatürde Suriyelilere yönelik algıyı araştıran çalışmalar da bulunmaktadır. Bu çalışmada yalnızca Türkiye'de Suriyelilere yönelik sosyal medya aracılı̆̆ıyla yapılan algı çalışmaları özetlenmiştir. Yapılan araştırmaların farklı araştırma sorularına yanıt aramaları nedeniyle belirli kriterlerle özetleyebilmek amacıyla araştırma bulgularında kullandıkları kavramlar en kapsayıcı haliyle kullanılmıştır.

Yazıcı (2016) Yeni Medyanın Nefret Dili: Suriyeli Mültecilerle Ilgili Ekşi Sözlük Örnĕgi başlıklı çalışmasında “Türkiye'de Suriyeli İstemiyoruz” başlığı altında yer alan yorumları analiz etmiştir. Yaptı̆̆ analiz neticesinde Suriyelilere yönelik nefret söylemlerinde ayrımcı, ötekileştirici ve yabancı düşmanlığı unsurlarını içeren ifadelerin yer aldığı bulgusuna ulaşmıştır. Söz konusu bulgularda Suriyelilere yönelik ekonomik tehdit, iç ve dış güvenliğe yönelik tehdit, Kurtuluş Savaşı, Toplumsal ve kültürel tehdit, Devlet/İktidar partisine yönelik eleştiriler de yer bulmaktadır. Öte yandan yorumlar arasında mültecilere yönelik merhamet etme, suçsuz görme ve Suriyelileri istemeyenlere yönelik eleştiriler de bulunmakla birlikte söz konusu yorumların oranının çok daha düşük düzeyde olduğu ifade edilmiştir.

Suriyelilere yönelik nefret söylemlerinin araştırıldı̆̆ı bir başka çalışmada Kurt (2019), Suriyeli 
sığınmacılara yönelik nefret söylemi içeren Youtube videolarını eleştirel söylem analiziyle değerlendirmiştir. Çalışma neticesinde Suriyeli sı̆̆ınmacılara yönelik iftira, ırkçılık ve düşmanlık içeren söylemlerin ağgrlıklı olduğu belirtilmiştir.

Özdemir ve Öner Özkan (2016), sosyal medya kullanıcılarının Suriyeli sı̆̆ınmacılara ilişkin sosyal temsilleri konulu çalışmalarında Suriyeli sığınmacıların dışlanma nedenlerini araştırmışlardır. Bu kapsamda Suriyeli sığınmacıların eleştirilen olumsuz özellikleri, tehdit algısı, Suriyelilere yönelik politikalara dair eleştiriler, Suriyelere yönelik olumlu yaklaşımlar, Suriyeli sı̆̆ınmacı sorununa yönelik çözüm önerileri ve diğer eleştiriler araştırmanın temaları olarak belirlenmiş̧tir. Mevcut temalar kapsamında sosyal medya kullanıcılarının Suriyelilerin Türkiye'de mevcut huzur ortamının, ekonomik ve sosyal yapıya karşı tehdit olarak algılandığı sonucuna ulaşılmıştır. Suriyelilere yönelik pozitif söylemlerim ise olumsuz söylemlere kıyasla daha düşük düzeyde olduğu belirlenmiştir.

Kardeş ve arkadaşları (2017), Ekşi sözlük örnekleminde Suriyeli sı̆̆ınmacılara yönelik algıyı araştırdıkları çalışmalarında Suriyeli sı̆̆ınmacıların toplumda güvensiz bir ortamın oluşmasına neden oldukları ve toplumsal huzura zarar verdikleri yönünde bir algının olduğu belirlenmiştir. Ayrıca hükümetin Suriyeli sığınmacılara yönelik politikalarına yönelik eleştirilerin ifade edildiği düşünülmektedir.

İşçi ve Uludağ (2019) Youtube'ta yer alan sokak röportajları örneklemi üzerinden Suriyeli algısı üzerine yaptığı araştırmada Suriyeli sığınmacılara karşı olan söylemlerin güvenlik, ekonomik, sosyokültürel, siyasi kaygı ve sebepsiz karşıt söylemlerden oluştuğunu, mültecileri destekleyen yapıcı sözler de bulunsa da bunların oranının düşük düzeyde kaldığını belirtmiştir.

Arslantürk (2020), sosyal medyada Suriyeli sı̆̆ınmacılara yönelik tutumları bütünleşik tehdit kuramı bağlamında değerlendirdiği çalışmasında Suriyeli sığınmacılara yönelik tutum içeren 131 tweet analiz etmiştir. Elde ettiği bulgular neticesinde Suriyeliler nedeniyle ortaya güvenlik, ekonomi ve istihdam, pozitif ayrımcılık gibi tehditlere neden oldukları belirtilmiştir. Sembolik tehdit olarak nüfusun artış hızı nedeniyle demografik yapının değişeceği, Türk etnik kimliğine yönelik tehdit, kültürel tehdit gibi unsurlar göze çarpmaktadır. Ayrıca Suriyelilere yönelik olumsuz kalıp yargıların olduğu belirtilmiştir. Öte yandan Suriyelilere yönelik olumlu içeriklerin yer aldığı belirtilmiştir. Bunlar genel olarak empati ve hoşgörü kaynaklı söylemler içermektedir.

Yıldırım ve Tekdemir Yurttaş (2016), sosyal medyada Suriyeli sı̆̆ınmacılara yönelik görüşlerini ifade edenlerin hangi dilsel kaynakları kullandıklarını eleştirel söylemsel psikoloji yaklaşımı ile analiz etmiştir. Ekşi Sözlük ve Uludă̆ sözlükte yer alan yorumların analiz edildiği çalışma kapsamında 7 farklı açıklayıcı 
repertuar keşfedilmiştir. Bunlar tehdit, öteki, Müslüman, empati, olması gereken mülteci repertuarı, uygulama sorunu repertuarı ve ekonomik yük repertuarıdır.

Taşdelen (2020), Suriyelilere yönelik nefret söylemlerini Teun Van Dijk'in söylem analizi yöntemi ile değerlendirdiği çalışmasında 1545 tweet ile içerik analizi yapmıştır. Yaptığı analizler neticesinde Suriyelilere yönelik istilacı, açgözlü ve ahlaksız gibi nefret söylemlerinin olduğunu, Suriyelilere karşı acıma duygusundan ziyade aşağılama ifadelerinin yer aldığı belirtilmiştir.

Yıldız (2018), Suriyeli sığınmacılara yönelik nefret söylemlerini çevrimiçi bir gazete ve Twitter'da Suriyeli sı̆̆ınmacılara yönelik tweetleri eleştirel söylem analiziyle karşılaştırmıştır. Yapılan araştırma neticesinde Suriyeli sı̆̆ınmacılara yönelik algının haberler vasıtasıyla üretildiği fakat Suriyeli sığınmacılara yönelik nefret söylemlerinin sosyal medya kanallarında yer aldığı belirtilmiştir. Mevcut nefret söylemleri küfür, hakaret, aşă̆ılamaların yoğun olarak kullanıldığı anlaşılmaktadır.

Sayımer ve Rabenda Derman (2017), Polonya ve Türkiye'de Suriyeli sığınmacılara yönelik korku ve tehlike söylemlerini Youtube videolarında yer alan yorumlar aracılığıyla araştırmışlardır. Yapılan araştırma neticesinde Suriyeliler kültüre ve ulusa yönelik bir tehdit olarak algılandığı, terörist, tecavüzcü ve hırsız olarak da damgalandı $\mathrm{g} ı$ belirtilmiştir.

Aldemir (2020), Hannah Arent'in düşüncesizlik ve yargı yetisinin kaybı ile ilişkili olarak ortaya koyduğu "kötülüğün sıradanlığı” kavramı bağlamında Twitter'da Suriyeli sığınmacılar hakkında atılan tweetleri analiz etmiştir. Suriyeli sı̆̆ınmacılara ilişkin nefret söylemlerinin kötülüğün sıradanlı̆̆ı ile ilişkilendirilmesinin mümkün olup olmadığının araştırıldığı çalışmada, yapılan söylem analizleri neticesinde sosyal medyanın kötülüğün yayılması için ortam hazırladığı ve kötülüğü yaygınlaşarak daha normal bir olgu olarak algılanmasına neden olduğunu belirtilmiştir.

Öksüz (2020), faşizmle mücadele etme bağlamında Ekşi Sözlük’te Suriyeli Sığınmacılarla ilgili metinler üzerinden söylem analizi yapmıştır. Yapılan söylem analizleri neticesinde kültürel aşağılama, ideolojik, biyolojik, ırkçı, milliyetçi, siyasi gibi nefret söylemleri ve çarpıtılmış bilgiler, komplo teorileri, suçlu gösterme gibi unsurlar belirlenmiştir.

Bayram (2020), Türk politik gençliğinin açısından Suriyeli mülteci krizini nasıl inşa ettiklerini araştırmaktadır. Bu bağlamda siyasi partilerin gençlik kollarına ait Twitter hesaplarında yer alan Suriyeli sığınmacılara dair tweetler analiz edilmiştir. Araştırma neticesinde Suriyeli krizine yönelik dindaşlık, soydaşlık, sınıftaşlık ve yurttaşlık temaları belirlenmiştir. Dindaşlık teması kapsamında Türk gençlerinin Suriyelileri dindaş olarak kabul ederken Türkmenleri soydaşlık nedeniyle kendilerine kapıların açılması 
gerekliliği belirtilmiştir. Dinle ilgili ifadelerde Suriye krizinde dinin kullanıldığına yönelik eleştiriler de yer almaktadır. Sınıftaşlık teması kapsamında ise Suriyeliler alt sınıf olarak görme eğiliminin olduğu belirlenmiştir. Bu durum yazara göre kapitalizmin bir sonucudur. "Suriyeliler biyolojik olarak insan" olarak kabul edilmekle birlikte Suriyeli mülteci krizinin merkezine yaşadıkları mağduriyet durumu konulmuştur. Bu bağlamda gençlik örgütleri Suriyeli mülteci krizine hümanist bir bakışla yaklaştıkları düşünülmektedir. Yurttaşlık temasında ise Suriyelileri Türk vatandaşlarına yönelen bir tehdit olarak görenler ve Suriyeli

\begin{tabular}{|c|c|c|c|c|c|c|c|c|c|c|c|c|}
\hline Yazar & Kaynak & 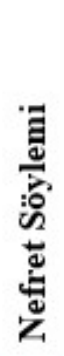 & 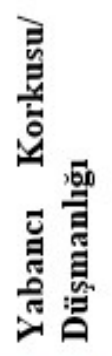 & 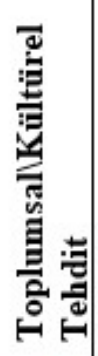 & 竘 & 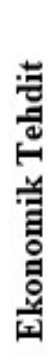 & 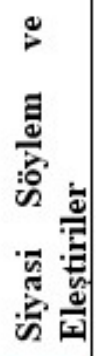 & 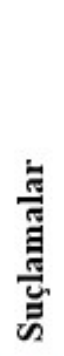 & 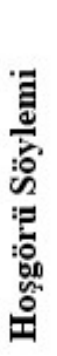 & 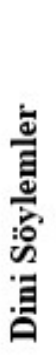 & 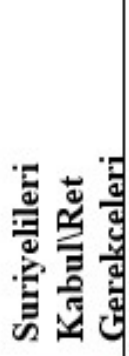 & 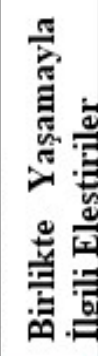 \\
\hline Yazıcı (2016) & $\begin{array}{l}\text { Ekşi } \\
\text { Sözlük }\end{array}$ & + & + & + & + & + & + & + & & & + & + \\
\hline $\begin{array}{l}\text { Özdemir ve } \\
\text { Öner-Özkan } \\
\text { (2016) }\end{array}$ & $\begin{array}{l}\text { Ekş̧i S. } \\
\text { İnci S. } \\
\text { İTÜ S. } \\
\text { Uludağ S. }\end{array}$ & + & & + & + & + & + & + & + & & + & + \\
\hline $\begin{array}{l}\text { Yldırım ve } \\
\text { Tekdemir } \\
\text { Yurttaș (2016) }\end{array}$ & $\begin{array}{l}\text { Ekşi S. } \\
\text { Uludağ S. }\end{array}$ & & + & + & + & + & & & + & + & + & + \\
\hline Öksüz (2020) & Ekși S. & + & + & & + & & + & + & & & & + \\
\hline $\begin{array}{l}\text { Arslantürk } \\
\text { (2020) }\end{array}$ & Twitter & + & + & + & + & + & + & + & + & + & + & + \\
\hline $\begin{array}{l}\text { Taşdelen } \\
(2020)\end{array}$ & Twitter & + & + & + & + & & & + & & & & \\
\hline Yildız (2018) & Twitter & + & & & + & + & & - & & & + & \\
\hline $\begin{array}{l}\text { Aldemir } \\
(2020)\end{array}$ & Twitter & + & & & & & + & + & & & + & \\
\hline $\begin{array}{l}\text { Bayram } \\
(2020)\end{array}$ & Twitter & + & & + & + & + & + & & + & + & + & + \\
\hline Kurt (2019) & YouTube & + & & & & & & + & + & & & \\
\hline $\begin{array}{l}\text { Sayımer ve } \\
\text { Rabenda } \\
\text { Derman } \\
(2017)\end{array}$ & YouTube & + & + & + & + & & & + & & & & \\
\hline $\begin{array}{l}\text { İsçci ve Uludağ } \\
\text { (2019) }\end{array}$ & YouTube & + & & + & + & + & + & & + & & + & + \\
\hline $\begin{array}{l}\text { Kardeş, } \\
\text { Banko ve } \\
\text { Akman (2017) }\end{array}$ & Youtube & + & + & + & + & + & + & + & + & & + & + \\
\hline Kuș (2016) & Facebook & + & & & + & + & & & & & & \\
\hline
\end{tabular}

Tablo 1: Sosyal Medyada Suriyelilerle İlgili Yapılan Çalışmalar 
mültecilerin sosyal tanımlarını reddeden iki grup belirlenmiştir. Genel olarak politik gençlik Suriyeli mülteci krizini Türkiye' nin diğer sorunlarıyla birlikte değerlendirdikleri ve bu bakımdan nesnel gerçeklikle bir arada yorumladıkları tespit edilmiştir.

Suriyeliler üzerine sosyal medyada yapılan çalışmaların ortak bulgularına bakıldığında nefret söylemlerinin, yabancı korkusunun, ekonomik, toplumsal-kültürel tehdit algısının ve güvenlik kaygılarının, suçlamaların fazla olduğu, hoşgörü ve dini söylemlerin ise daha düşük düzeyde kaldı̆̆ı göze çarpmaktadır. Genel olarak olumsuz bir algının ağırlık taşıdığına dair bulguların bulunmuş olması Suriyelilerin toplumun güven ve huzur ortamını olumsuz etkilediği algısının yaygın olduğunu göstermektedir. Olumsuz algının ağırlıkta olmasında Suriyelilerin ülkelerine ne zaman döneceklerinin henüz belirsiz olması ve yoğun nüfusları nedeniyle Türk toplumu içinde görünürlüklerinin kolay olmasının etkisi görülmektedir. Türk toplumuna entegre olmalarının gecikmesi, toplumsal yaşamda miksofobiye neden olmaktadır. Bauman'ın (2019, s.15) ifadesiyle miksofobi (baş edilmez ölçüde bilinmez, ehlileştirilemez, itici ve denetlenemez şeylerden duyulan korku) şehrin caddelerini rahatsız edici, kafa karıştırıcı ve ürkütücü bir karmaşa olarak görülmesine, zenginlerin "güvenlikli yaşam alanı” satın almasına neden olurken geri kalanların kaygı ve korkuya kapılmasına neden olmaktadır.

\section{4. Ötekiyle Birlikte Yaşama Deneyimi Olarak Suriyeli Sığınmacılar Hakkında Türk Toplumunun Görüşleri}

\subsection{Araştırmanın Amaç ve Önemi}

Suriyeliler için ülkelerindeki belirsizliğin devam etmesi nedeniyle Geçici Koruma statüsünde ülkede kalma süreleri de henüz belirsizdir. Bu nedenle Türkiye'de bulunacakları süreç için toplumsal, ekonomik ve güvenlik sorunlarına neden olmamaları ve bu bağlamda Türk toplumuna entegre olmaları önem taşımaktadır.

Şüphesiz entegrasyon yalnızca yabancıların geldikleri topluma tek yönlü uyum sağlaması ile mümkün değildir. Bunun diğer ayağını ise yerel halk oluşturmaktadır. Geldikleri yerin yabancısı olan göçmen gruplarına yönelik algı, her iki grup arasındaki bağların kurulmasını kolaylaştırabileceği gibi zorlaştırması da mümkündür. Bu bağlamda Suriyeli sığınmacılara yönelik algının araştırıldığı nicel ve nitel birçok saha çalışması bulunmaktadır. Benzer şekilde günümüzde sosyal medyanın aktif biçimde kullanılıyor olması nedeniyle sosyal medya siteleri örnekleminde de Suriyeli algısı çalışmaları yapılmıştır. Yapılan bu çalışmalara bakıldığında (Tablo 1) genel olarak Suriyelilere yönelik nefret söyleminin yaygın olduğu 
görülmektedir. Ayn zamanda Suriyeliler nedeniyle toplumsal düzenin ve ülkenin refah düzeyinin olumsuz etkilendiğine dair eleştiriler de yer almaktadır. Buna ek olarak yerel halkın güvenlik kaygılarının olduğu da görülmektedir.

Yukarıda ifade edildiği üzere sosyal medya üzerinden yapılan Suriyeli algısı araştırmalarında genel olarak Suriyelilere yönelik algı ve görüşlerin hangi konularla ilgili olduğunun ve nefret söylemi ifadelerinin belirlenmesi amaçlanmıştır. Bu araştırma kapsamında ise Suriyelilere İŞKUR aracılığıyla iş verileceğine yönelik çarpıtılmış bir haber nedeniyle gündem olan “\#Suriyeli” etiketi (hahstag) ile atılan tweetlerde Suriyeli sığınmacılara yönelik algı ve görüşlerde en çok hangi konulara değinildiğinin belirlenmesi ve çalışma hakkı ile ekonominin Suriyeli algısı üzerindeki etkisinin belirlenmesi amaçlanmıştır. Belirlenen amaç doğrultusunda araştırmanın ana problemi ve alt problemleri şöyledir:

Ana problem, "Yaklaşık 10 yıldır Suriyelilerle birlikte yaşama deneyimi olan Türk toplumunun Suriyelilere ilişkin algı, deneyim ve görüşleri sosyal medyada en fazla hangi konularda yoğunlaşmaktadır?" olarak belirlenmiştir. Alt problemleri ise;

- “\#Suriyeli” başlık etiketi Suriyelilere iş verilmesiyle ilgili çarpıtılmış bir haber nedeniyle Twitter'da ülke gündemine girmiştir. Bu doğrultuda Suriyelilere yönelik algı ve görüşleri belirleyen ana unsur çalışma hakkı ve ekonomiyle ilgili algı ve görüşler midir?

- Suriyelilere yönelik yapılan yorumlarda görüş farklılıkları var mıdır? Eğer varsa söz konusu farklılıkları oluşturan unsurlar nelerdir?

- Sosyal medyadaki mesajlar ne tür ayrımcı ve dışlayıcı (nefret söylemi, ırkçılık, cinsiyetçilik, vb.) temalar içermektedir?

\subsection{Araştırmanın Yöntemi ve Veri Toplama Tekniği}

Araştırmanın amacı doğrultusunda insanların algı ve görüşleri hakkında bilgi edinebilmek amacıyla nitel araştırma metodolojisi kapsamında fenomenolojik araştırma deseni esas alınmıştır. Fenomenolojik araştırmalarda "İnsan grubu veya kişinin bu fenomene ilişkin deneyiminin anlamı, yapısı ve özü nedir?" temel sorusunun yanıtı aranmaktadır (Patton, 2014, s.104). Buradan hareketle Türk toplumundan etnik, kültürel ve dil bakımından farklı olan Suriyeli sığınmacılara yönelik algı ve deneyimlerinin araştırılması fenomenolojik bir desen için uygundur. 


\subsection{Araştırmanın Evreni, Örneklemi}

Aile, Çalışma ve Sosyal Hizmetler Bakanlığı ile İŞKUR tarafından Dünya Bankası iş birliği ile hayata geçirilen "Geçici Koruma Altındaki Suriyeliler ve Türk Vatandaşları İçin İstihdam Desteği Projesi" kapsamında 7.400 Suriyelinin ve 7.400 Türk vatandaşının proje kapsamında 30 aylık istihdamıyla ilgili İŞKUR ilanı yayımlanmıştır. İŞKUR tarafından projenin ilan edilmesinin ardından Twitter adlı sosyal medya sitesinde yer alan "\#Suriyeli” başlıklı etiketi (hashtag) 16 Ocak 2020 tarihinde Türkiye gündemine girmiştir. Bu kapsamda araştırmanın evreni söz konusu tarihte atılan toplam 6449 gönderiden oluşmaktadır. Araştırmanın örneklemi evren içinde analize uygun 1231 gönderidir. Örneklem sayısı öncelikle konuyla ilgili olmayan gönderiler ve başkalarının gönderilerini herhangi bir ekleme yapmadan (yeniden üretmeden) tekrar paylaşan gönderilerin (retweet) belirlenerek ayıklanmasıyla ulaşılmıştır.

\subsection{Verilerin Analizi}

Twetter'dan çekilen gönderilerin analizinde nitel veri analiz programı MAXQDA aracılığıyla tematik içerik analizi yapılmıştır. Söz konusu gönderilerin analizinde öncelikle temalar belirlenmiş ve her tema için alt tema ve alt kodlar belirlenerek kodlamalar yapılmıştır. Kod, yazılı, görsel veya konuşma içerikli bir veriyi betimlemek amacıyla içeriğin özünü özetleyen kelime veya kısa ifadelerdir (Saldana, 2019, s.4). Bu araştırmada bütüncül bir analiz yapabilmek için "ana kodlama (temalar)/iç içe kodlama alt kodlar)" ve "In Vivo (harfiyen kodlama/motamot kodlama/tümevarımsal kodlama) tekniği bir arada kullanılmıştır. Alt kodlama tekniğine göre her söylem öncelikle temalarla/ana kodlarla kodlanmış ardından söylemin içeriğine göre hiyerarşik düzeyde alt kodlar oluşturulmuştur (Saldana, 2019, s.93). In Vivo tekniği ise söylemler içerisinde yer alan ana unsurlar veya tüm söylemi özetleyecek en kısa ifadeler ile yapılan kodlamay1 ifade etmektedir (Saldana, 2019, s.105).

\subsection{Bulgular}

Bu bölümde öncelikle araştırmada yer alan temalar ve alt kodlara dair genel bilgiler söz konusu tema ve alt temaların oranları verilmiştir. İkinci aşamada ise Suriyeli sığınmacılara karşı söylem ve değerlendirmeler için oluşturulan tema ve alt kodların neler olduğu ve söylemlerde yer alma oranları verilecektir.

Öteki ile ilgili mevcut literatürden de faydalanarak oluşturulan temalar "Sosyal Ilişskiler", "Nefret 
Söylemleri”, “Suriyelilerin Kabul Edilmesi veya Edilmemesiyle Illgili Gerekçeler”, “Siyasi Söylemler”, “Çalışma Hakkı”, “Hoşgörü Söylemleri”, Ekonomi”, “Suçlamalar” ve “Vatandaşlık” şeklindedir. Bu temalarla hiyerarşik ilişki içinde olan alt kodlar da bulunmaktadır.

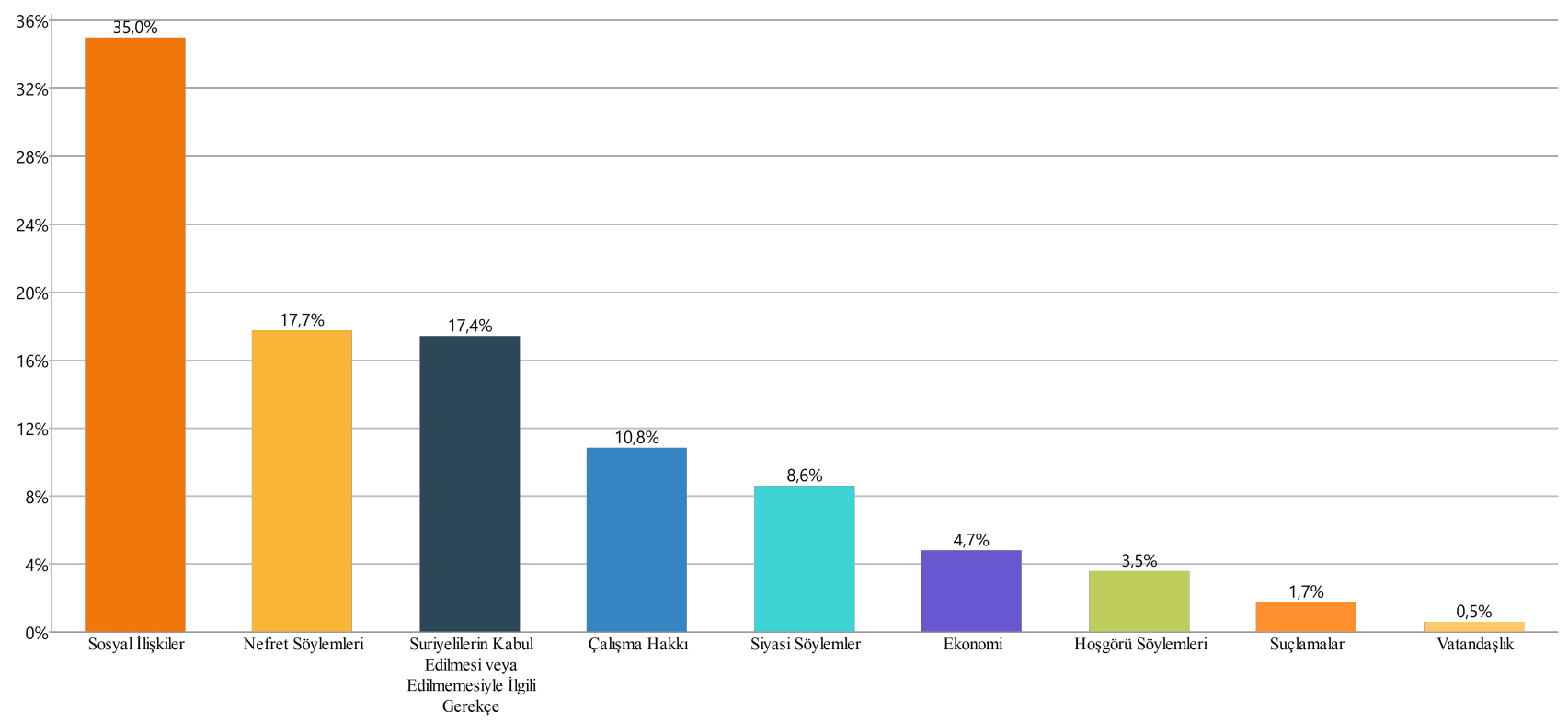

Şekil 1. Ana Temaların Toplam Kodlanma Oranları

Ana temalara dair sıralama frekans azalan kriterine göre yapılmıştır. Buna göre Suriyelilerle ilgili söylemlerde en fazla değinilen husus sosyal ilişkilerle ilgilidir $f(1731)$. Nefret söylemleri $f(877)$, Suriyeli sı̆̆ınmacıları ülkeye kabul edilmesi veya reddedilmesiyle ilgili söylem ve gerekçeler (859), Çalışma hakkı $f(536)$, Siyasi söylemler $f(424)$, Ekonomi $f(235)$, Hoşgörü söylemleri $f(175)$, Suçlamalar (85) ve Vatandaşlık ile ilgili ifadeler $f(27)$ kez gönderilerde yer almıştır.

Suriyeliler hakkında yazılan gönderilerde sosyal ilişkilere dair unsurlar birinci sırada yer alırken çalışma hakkının dördüncü, ekonominin ise altıncı sırada yer alıyor olması, Suriyelilere yönelik algının temel nedeninin ekonomi ve çalışma hakkıyla ilgili unsurlardan ziyade sı̆̆ınmacı, etnik ve ulus kimliklerinden kaynaklı bir arada bulunmaktan kaynaklanan kültürel hoşnutsuzluklardan kaynaklandığı düşünülmektedir. Başka bir ifadeyle Suriyelilere yönelik olumsuz algının ve istenmemelerinin ana nedeni emek piyasasında yer almaları ve ekonomi üzerindeki etkileri değildir. Şüphesiz bu unsurlar mevcut algı ve tutumun oluşmasında etkili olmakla birlikte ana unsur değildir.

\subsubsection{Sosyal İlişkiler}

Sosyal ilişkiler teması, Türk toplumu ile Suriyeli sı̆̆ınmacıların bir arada yaşama deneyimleri ne- 
ticesinde oluşan görüşlerini yansitmaktadır. Bu doğrultuda üç tema ve bu temalar altında alt kodlar belirlenmiştir.

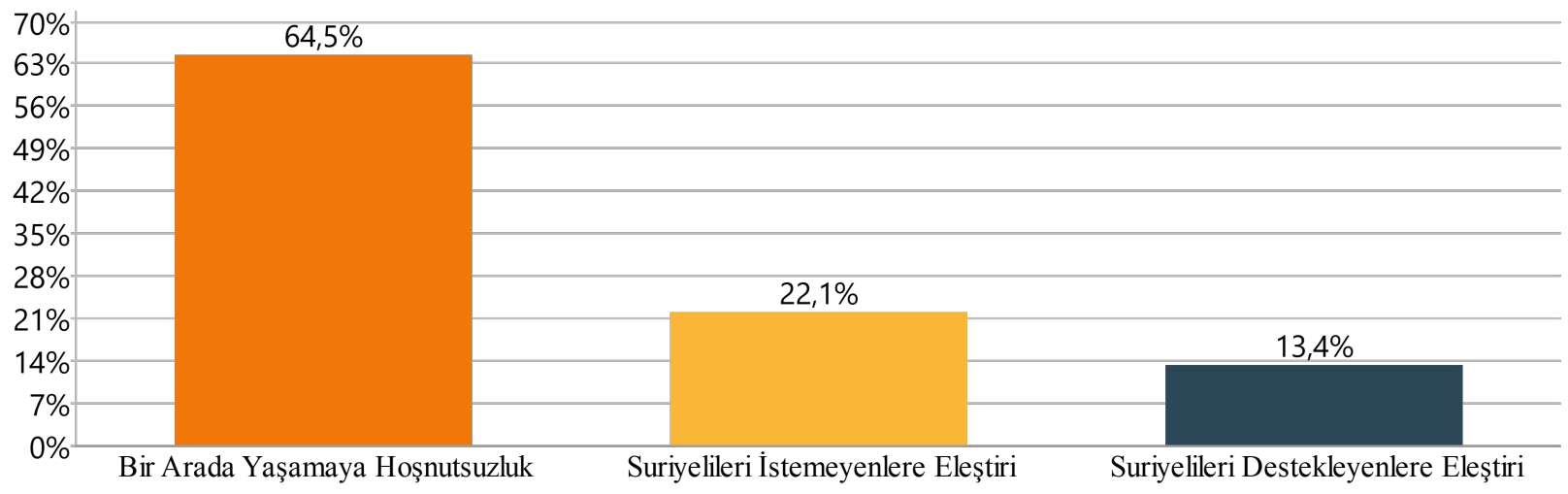

Şekil 2. Sosyal İlişkiler Temasına Ait Alt Temaların Oranları

Suriyeliler Türk toplumuna katılmasıyla birlikte geçen sürede Suriyelilere yönelik söylemlerin üçe ayrıldığı görülmektedir. Söz konusu görüş ayrılıkları Suriyelilerle “Bir arada yaşamaya hoşnutsuzluk”, Suriyelilere olumsuz bakanların "Suriyeli sı̆̆ıımacıları destekleyenlere yönelik eleştirileri” ve Suriyeli sığınmacıları destekleyenlerin “Suriyeli sığınmacıları istemeyenlere yönelik eleştirileri” şeklinde üçe ayrılmaktadır. Böyle bir ayrımın oluşması, dış grup olarak Suriyelilere karşı toplumun birlikte yaşama deneyimini farklı algıladıklarını göstermektedir.

Bir arada yaşamaya hoşnutsuzluk teması altında "Suriyelilere pozitif ayrımcılık ve taviz”, “Çok çocuk yapmaları”, “Ülkede keyif çatmaları”, "Savaştan kaçarak ülkelerine sahip çıkmadıkları”, “Kalabalık olmaları ve demografik yapıyı değiştirmeleri”, “Ahlak ve huzuru bozmaları, düzen bırakmadıkları”, “Insanların iyi niyetlerini suiistimal etmeleri” ve "Türkçe öğrenememeleri” alt kodları yer almaktadır.

Suriyelileri istemeyenlere eleştiri teması altında "Vicdansız/zalim olmayın”, "Irkçılık yapıyorsunuz”, “Suriyeliler hakkında yalan yanlış haberler yapıyorsunuz”, “Medya toplumu Suriyelilere karşı kışkırtıyor”, “Kin ve nefret dolusunuz”, "Vatanlarından isteyerek ayrlmadılar”, "Suriyelileri istismar ediyorsunuz”, "Hepimiz insanız", "Herkes bir yerlerden bu topraklara göç etti” ve "Suriyelilerin kimseye zararı yok" alt kodları yer almaktadır.

Suriyelileri destekleyenlere yönelik eleştiri teması altında ise "Misafirperverliğe eleştiri/Mazlum edebiyatı”, “Arap seviciliği”, “Suriyelileri savunmak vatana ihanettir”, "Fazla duyarlı davranıllyor”, “Suriyelileri destekleyenler de gitsin”, “Doğu Türkistan'a destek olmuyorsunuz”, “Suriyelileri istememek ırkçılık değildir” alt kodları yer almaktadır. 
Kimliğin iç grupta bütünleştirme, dış gruplara karşı ise ayrıştırma işlevi Suriyelilerle birlikte yaşama deneyiminde mevcut söylemlerin oluşmasını etkilediği görülmektedir. Kimliğin bu işlevi, Suriyeli sı̆̆ınmacılara hoşgörüyle bakanların da benzer hoşgörüsüzlükten nasibini almasına neden olmaktadır. Başka bir ifadeyle farklı bir etnisite ve ulus kimliğine mensup Suriyelilere yönelik olumlu söylemlerde bulunanlara karşı yapılan eleştiriler, Suriyelilerin kendisi kadar olmasa da iç grup kimliğine yönelik bir tehdit olarak algılanmaktadır. Örneğin; “Arap seviciliği”, “Suriyelileri savunmak vatana ihanettir”, “Doğu Türkistan'a destek olmuyorsunuz” gibi ifadeler, farklılıkları nedeniyle öteki olarak kabul edilen Suriyeliler ve Suriyelere hoşgörüyle yaklaşanlara karşı Türk kimliğini koruma amacıyla yapıldığı düşünülmektedir. Benzer şekilde Suriyelileri savunanlar da Suriyelileri istemeyenlere yönelik eleştirel söylemlerde bulunmaktadır. Bu eleştirilerin temelinde etnik kimlik ve ulus kimlik vurgusunun bulunmadı̆̆ sikliği ile itham edildikleri görülmektedir. Benzer bir bulgu Arslantürk’ün (2020, s.10) Twitter üzerinden yaptığı araştırmada yer almaktadır. Suriyeliler hakkında olumsuz tweet atan hesaplarda etnik kimliğe, ulus kimliğine veya ideolojik yelpazenin solunda yer alan partilere ilişkin hesaplarında resim, sembol ve slogan bulunun kişiler tarafından atılmıştır. Suriyeliler hakkında olumlu tweet atanlar ise dini kimlik ve ideolojik yelpazenin sağında yer alan partilere ilişkin hesaplarda ilgili resim, sembol ve slogan bulunan kişiler tarafindan atılmıştır.

\subsubsection{Yabancı Korkusu ve Nefret Söylemleri}

Nefret söylemi adlı kategori 6 tema ve bu temalara bağlı alt kodlardan oluşmaktadır. Nefret söylemi tanımlarında "etnik merkezci söylemler" ve "yabancı korkusu” ve "ayrımcı söylemler" nefret söylemi olarak kabul edilmesi nedeniyle farklı bir kategori olarak değerlendirilmemiştir. Etnik merkezci söylemler aynı zamanda milliyetçi söylemleri de ihtiva ettiği için ikisi bir arada değerlendirilmiştir.

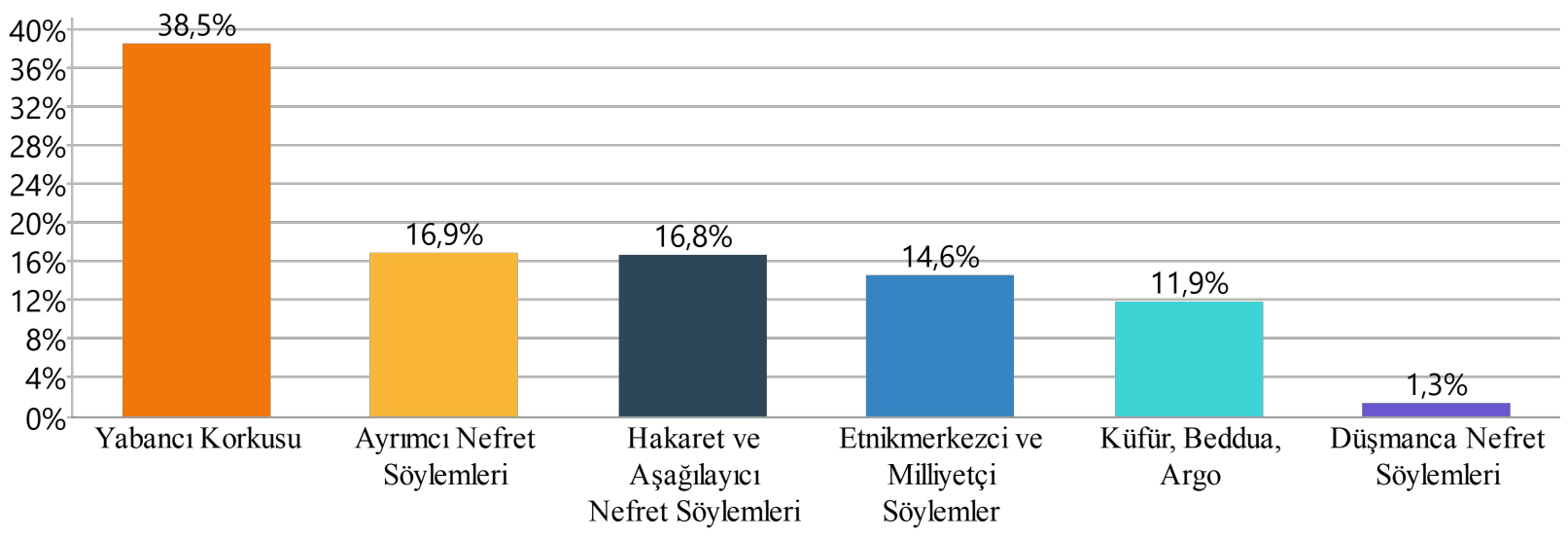

Şekil 3. Yabancı Korkusu ve Nefret Söylemleri Temasına Ait Alt Temaların Oranları 


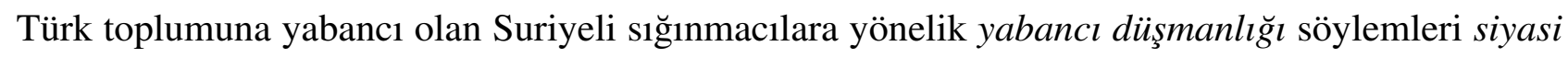
korku üzerinde yoğunlaşmaktadır. Bunu güvenlik korkusu ve kültürel değişim korkusu izlemektedir.

Siyasi açıdan korku, Suriyelilerin nüfusun yoğunluğunun fazla olması, çok fazla doğum yapmaları ve bu nedenle yeni bir azınlık oluşacağı yönündeki eleştiriye dayanmaktadır. Öte yandan Suriyelilerin toprak isteyeceği, ülkeyi ele geçirecekleri yönünde korkular da yer almaktadır. Suriyelilere yönelik bu tür korkuların kaynağı Türkiye Cumhuriyeti’nin tarih kitaplarında Suriyelileri ötekileştirmesinden kaynaklanıyor olması mümkündür. Kırıkçı (2017, s.349) yaptı̆̆ı çalışmada tarih ders kitaplarında Suriye hakkında "Türk topraklarına göz diken” ve "tehdit” gibi ifadelerin yer aldığını belirtmektedir. Buna ek olarak Araplara yönelik kalıp yargılar ve ayrımcı deyimlerin varlığı da söz konusu yabancı korkusunun temelini oluşturması mümkündür. Örneğin, “Ne Şam’1n şekeri, ne Arap’ın yüzü” deyişi ile Araplardan hayır gelmeyeceği, "Anladıysam Arap olayım” deyimi ile mevcut durumun ne kadar saçma ve anlamsız olduğu, "Arap eli öpmekle dudak kararmaz” atasözü ile ırkçı bir ifade ile kirli, pis bir şeyle temas edenin kirlenmeyeceği ifade edilmektedir (ayrimcisozluk.blogspot.com). Bu ve benzeri deyim ve atasözleri öteki olarak Suriyelilere yönelik yabancı korkusunu tetikleyen kalıp yargı ve önyargı unsurları olarak görülebilir.

\subsection{3 Ülkedeki Suriyelileri Destekleyenler ve Suriyelileri İstemeyenlerin Gerekçeleri}

Suriyelilere karşı toplumun iki farklı görüşe sahip olmasının dayanağı Suriyeli sı̆̆ınmacıların ülkede olmalarına bakış açılarıyla ilgilidir. Bu doğrultuda Suriyelileri destekleyenler ve onları istemeyenlerin görüşleri doğrultusunda iki tema yer almaktadır. Bu temalarla ifade edilmek istenen aslında birlikte yaşamayı kabul etmek veya reddetmek şeklinde de düşünülebilir. Dolayısıyla Suriyelilerle birlikte yaşamayı kabul edenlerin ve reddedenlerin birtakım gerekçeleri de bulunmaktadır. Bu gerekçeler alt kodlarda ifade edilmiştir.

Yapılan analiz sonucunda elde edilen bulgulara göre Suriyelileri istemeyenlerin gerekçeleri Suriyelileri destekleyenlerin gerekçelerinden daha fazladır. Benzer şekilde Twitter'da Suriyeli istemediğini ifade eden gönderilerin sayısı Suriyelileri destekleyenlerin sayısından çok daha fazladır. Suriyelileri istememe gerekçeleri altında “Tüm sı̆̆ınmacıları (Afgan, Iraklı, Pakistanlı, Özbek) istemiyorum”, “Suriyeli erkekler savaşmalı”, “Yıllardır elimizden geleni yaptıkfakat artık yeter”, “Ülkemde Arap istemiyorum”, "Suriye'de çatışmalar bitti”, “Bayramlaşmak için gidiyorlar, tamamen gitsinler”, “Güvenli bölgeye gitsinler”, Gidip ÖSO’ya katılsınlar” alt kodları yer almaktadır. Suriyelileri kabul gerekçeleri arasında ise "Suriye ile tarihsel bă̆larımız var”, "Din, ırk ayrımı olmamalı”, "Suriye'deki savaş ve belirsizlik devam ediyor”, “Din kardeşiyiz” alt kodları yer almaktadır. 


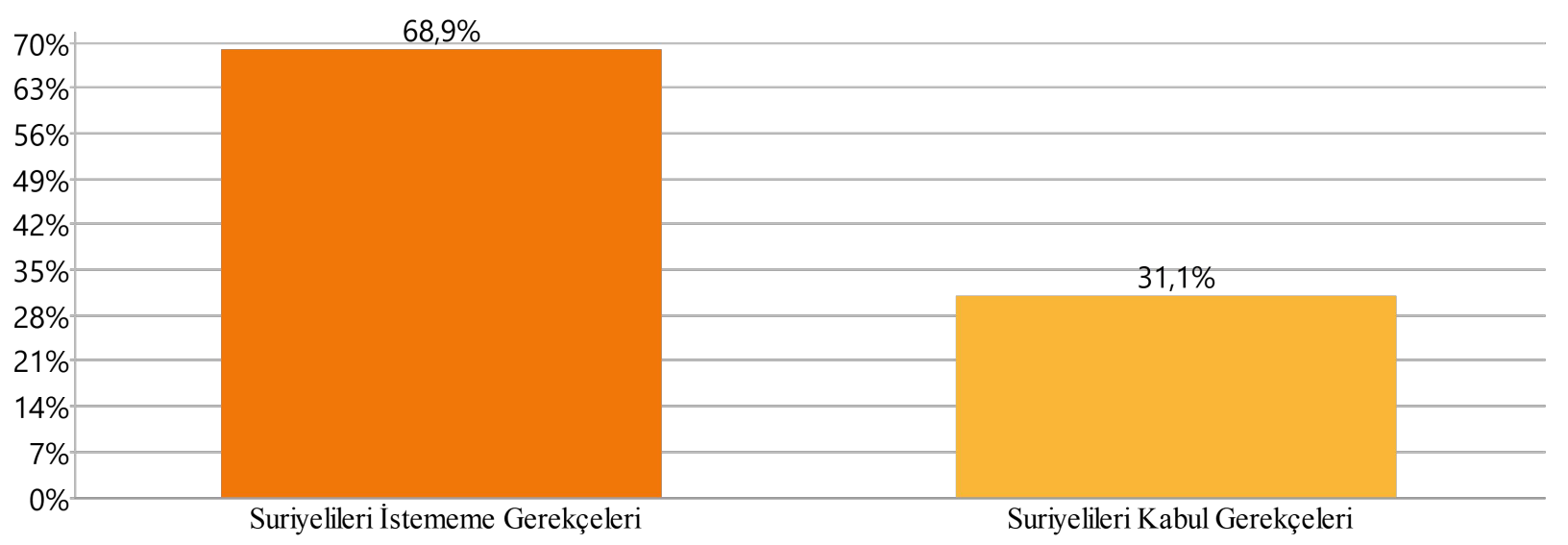

Şekil 4. Suriyelilerin Ülkeye Kabul Edilmesi veya Reddedilmesiyle İlgili Gerekçelerle İlgili Temaların Oranları

Ülkemde Suriyeli istemiyorum diyenler aynı zamanda ülkede tüm göçmenleri kapsayacak şekilde göçmen istemediklerini belirttikleri de görülmektedir. Bu durum şaşırtıcı değildir. Daha önce yapılan çalışmalarda da benzer sonuçların olduğu görülmektedir. Bu çalışmalar arasında en kapsamlı olanlardan biri Suriyeli Barometresi'dir. Barometrede “Türkiye’de bulunan Suriyeliler nerede yaşamal1?” sorusuna 2017 y1lında \%37,4 ve 2019 y1lında \%44,8 düzeyinde "Suriye'de kurulacak güvenli bölgelere gönderilmeli ve orada yaşamalılar" yanıtı verilmiştir. "Her halükârda gönderilmeliler” diyenlerin oranı 2017 yılında \%11,5 düzeyindeyken 2019 yılında \%25 düzeyine yükselmiştir. "Sadece kamplarda yaşamalılar” diyenlerin oranı 2017 yılında \%28,1 ve 2019 yılında \%15; “Türkiye'ye dengeli dağıtılmalı” diyenlerin oranı 2017 yılında \% 7,7 ve 2019 yılında 5,5; "İstedikleri şehirde yaşayabilmeli” diyenlerin oranı 2017 yılında 7,9 ve 2019 yılında 5,3 düzeyindedir (Erdoğan, 2020, s.98).

Suriyeleri istemeyenlerin görüşlerine bakıldığında "etnik kimlik” üzerinden vurgu göze çarparken, Suriyelilerin ülkede bulunmasını olumlu karşılayanların dini hassasiyetlerinin öne çıktığı görülmektedir. Nitekim “Hoşgörü söylemleri” teması altında da mevcut hoşgörü algısının temel dayanaklarından birinin dini hassasiyet olduğu görülmektedir. Fakat hem Suriyelileri istemeyenlerde etnik kimliğe vurgu oranının yüksek olması hem de dini söylemlerin düşük düzeyde kalması, Türklerin ve Suriyelilerin büyük ölçüde Müslüman olmasına rağmen aynı dine mensubiyetin bir ortaklık duygusu yaratmada etkisinin sınırlı olduğunu göstermektedir. Bunun nedeni Vamık Volkan'ın (2017, s.26) da ifade ettiği gibi kimi durumlarda etnik bağın, dini bağın önüne geçmiş olmasından kaynaklanıyor olabilir.

\subsection{4 Çalışma Hakkı}

Çalışma hakkı kategori altında yer alan tema ve kodlar In Vivo yöntemiyle kodlanarak elde edilmiştir. 
Buna göre çalışma hakkı altında yer alan temalar Türk vatandaşlarının işsizliği, Suriyelilere iş verilmesine eleştiri, Suriyelilere iş verilmesine destek ve ucuza çalıştıkları yönündeki eleştiriler ile Türklerin işini elinden alıyorlar şeklindeki eleştirilerden oluşmaktadır.

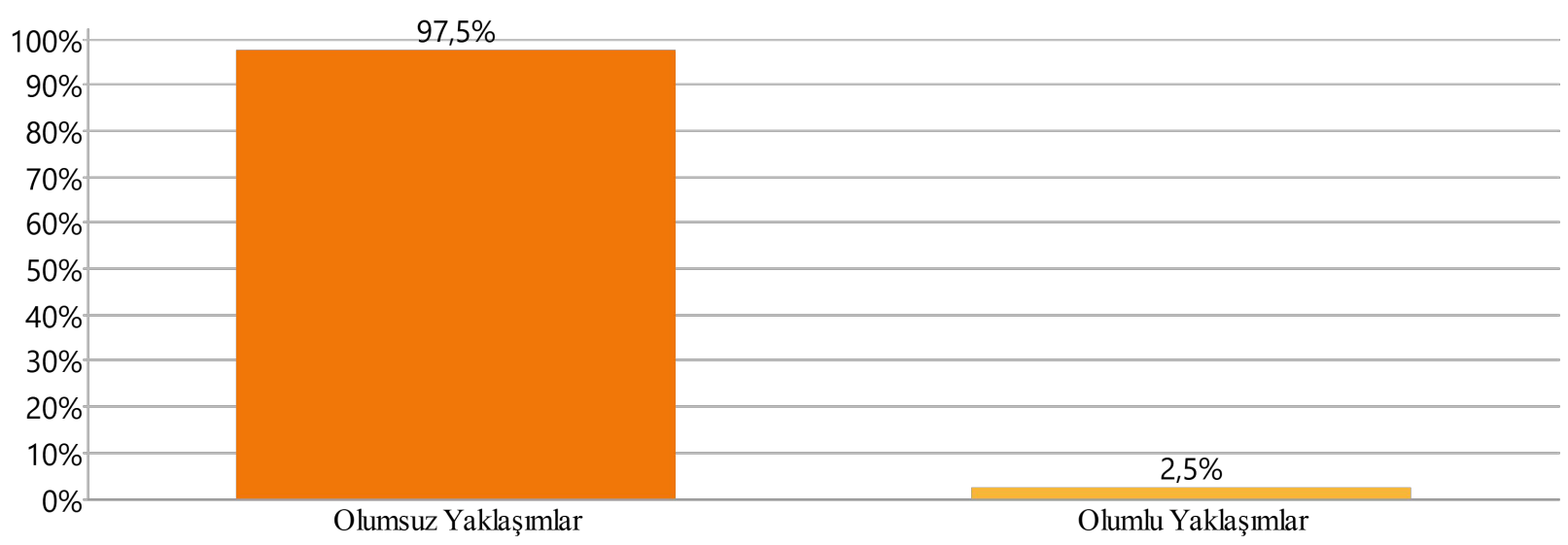

Şekil 5. Çalışma Hakkı Temasına Ait Alt Temaların Oranları

Çalışma hakkı teması toplamda 536 kodlama ile tüm ana temalar arasında en fazla kodlama yapılan dördüncü tema konumundadır. Söz konusu temanın alt temalarına bakıldığında Suriyelilere çalışma hakkı verilmesine yönelik \% 97,5 düzeyinde olumsuz yaklaşımın olması genel olarak “Türklerin işini elinden alıyorlar” ve “Türk vatandaşlarının işsizliği”" söylemlerine dayanmaktadır. Öte yandan Çalışma hakkı hususunda olumlu görüşlerin \%2,5 ile çok düşük düzeyde kalmış olması Suriyelileri ülkeye kabul eden kesimin de çalışma hakkı konusunda olumsuz yaklaştığını veya çekimser olduğunu göstermektedir.

Göçmenlerin geldiği yerin sosyal yaşamına entegre olmalarının yanı sıra ekonomik yaşama da entegre olmaları gereklidir. Fakat hem etnik kimlikleri hem de ülkede sı̆̆ınmacı olmaları nedeniyle Suriyelilerin ekonomik entegrasyonuna ve çalışma hakkı verilmesine Türk halkı olumsuz bakmaktadır. Bu durum sığınmacıların ekonomi üzerindeki etkisi ve çalışma hayatında rekabeti arttırmaları ile açıklanabileceği gibi kimlik iktisadı açısından da değerlendirilebilir. Akerlof ve Kranton (2016) tarafından ortaya atılan bu görüşe göre ekonomik davranışlarda modellere mübadele dışı, parasal olmayan unsurları da dahil etmemiz gereklidir. Çünkü ekonomi tıpkı sosyo-kültürel unsurlar gibi ötekileştirici bir unsurdur.

\subsubsection{Siyasi Söylemler}

Siyasi söylemler teması altında yer alan alt tema ve alt kodlar In Vivo yöntemiyle kodlanarak elde

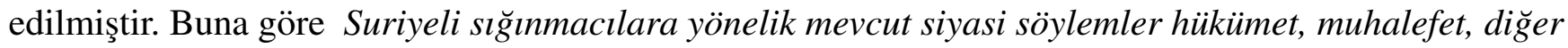
ülkelere yönelik eleştirilerle ilgilidir. 


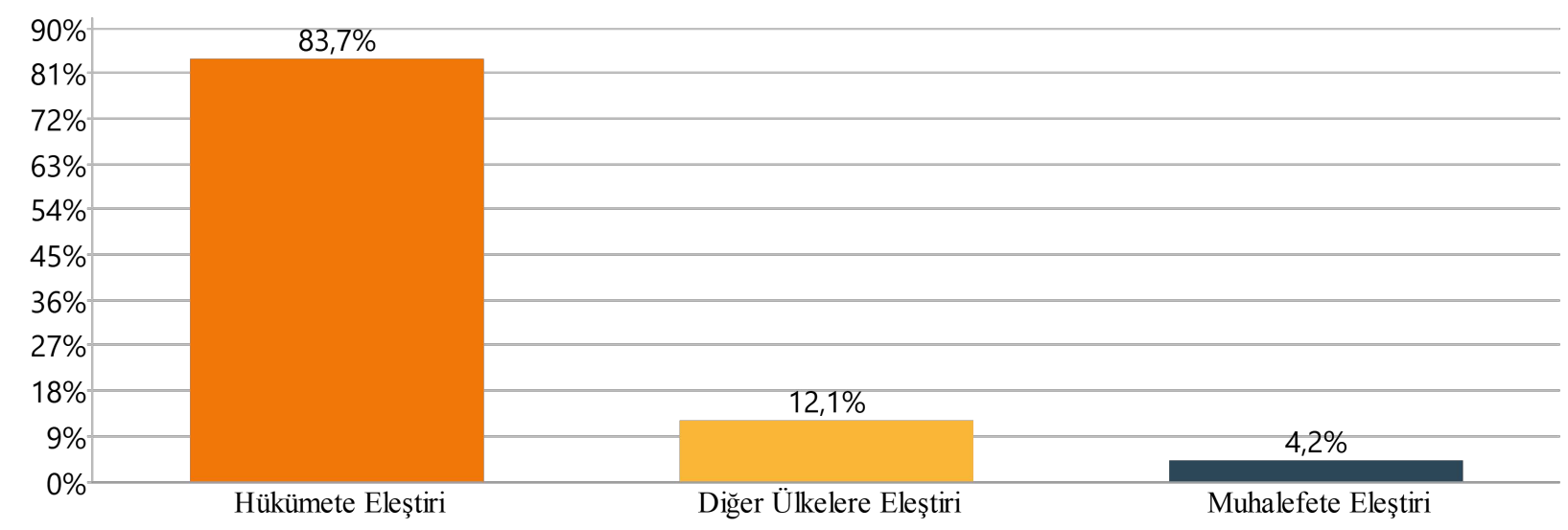

Şekil 6. Siyasi Söylemler Temasına Ait Alt Temaların Oranları

Hükümete yönelik eleştiriler “Türk askerlerinin şehit olması”, “Göç politikasına eleştiri”, “Suriyelileri koruyalım derken kendi halkımız măgdur ediliyor" ve "Suriye’ye müdahaleye eleştiri” alt kodlarından oluşmaktadır. Muhalefet partilerine yönelik eleştiri ise Birlikte Yaşama teması altında yer alan Suriyelileri istemeyenlere yönelik eleştiri ile ilişkili olduğu belirlenmiştir. Diğer ülkelere eleştirileri ise "Rusya ve Iran'a eleştiri”, "Suriye rejimine eleştiri”, “Avrupa ülkelerine eleştiri” ve "Arap ülkelerine eleştiri” alt kodlarından oluşmaktadır.

\subsubsection{Suriyelilere Yönelik Ekonomik Nedenli Söylemler}

\#Suriyeli başlık etiketi Twitter'da çalışma hakkı ve bu bağlamda ekonomiyle ilgili bir nedenden dolayı ülke gündemine girmiş olmasına rağmen tüm temalar arasında çalışma hakkı teması dört, ekonomi teması ise altıncı sırada yer almaktadır. Ekonomi teması altında değerlendirilen alt temalar ekonomiye ilişkin olumlu söylemler ve olumsuz söylemler şeklinde ikiye ayrılmıştır.

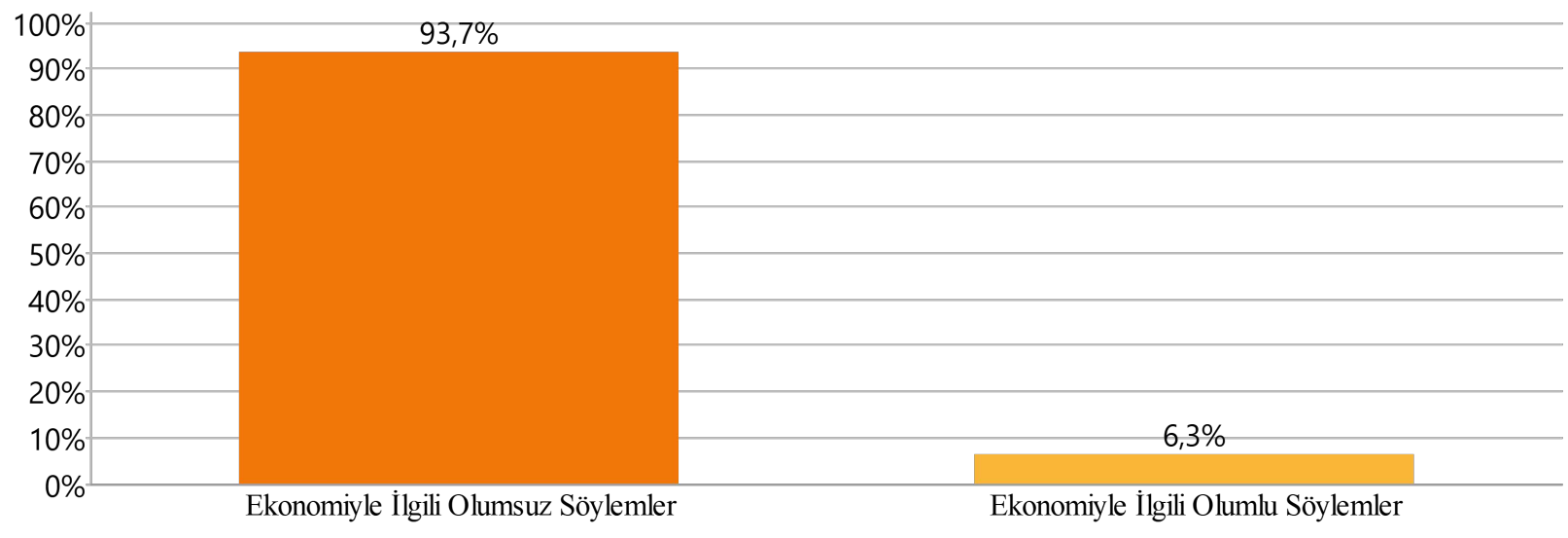

Şekil 7. Ekonomi Temasına Ait Alt Temaların Oranları 
Ekonomi temasını oluşturulan temalara bakıldığında yapılan yorumlarda Suriyeli sı̆̆ınmacıların ülke ekonomisini olumsuz etkilediği, Suriyelilere ekonomik yardım yapılmasından hoşnut olunmadığı ve Türk vatandaşlarının vergilerinin Suriyeliler için harcanmasının istenmediği görülmektedir. Öte yandan ekonomiyi olumlu yönde etkiledikleri ve ülke ekonomisinin kötü gidişatından Suriyelilerin sorumlu olmadıklarını dile getiren yorumlar da yer almaktadır.

Ekonomi ve çalışma hakkı kategorisi birlikte değerlendirildiğinde Suriyelilere yönelik eleştirel söylem ve suçlamaların çok yoğun bir şekilde yer aldığı görülmektedir. Aynı zamanda Türk vatandaşlarının işsizliğinin eleştirilmesi ile Osmanlıya ihanet eden/bizi sırtımızdan vuran suçlama teması arasında ilişkinin de olduğu belirlenmiştir. Nitekim bu durum Suriyelilerin bir öteki olarak varlıklarının Türkiye’ye göç ederek sığınmalarıyla başlamadığının bir başka delili niteliğindedir.

\subsubsection{Hoşgörü Söylemleri}

Bu kategori altında yer alan temalar In Vivo kodlama yöntemiyle belirlenmiştir.

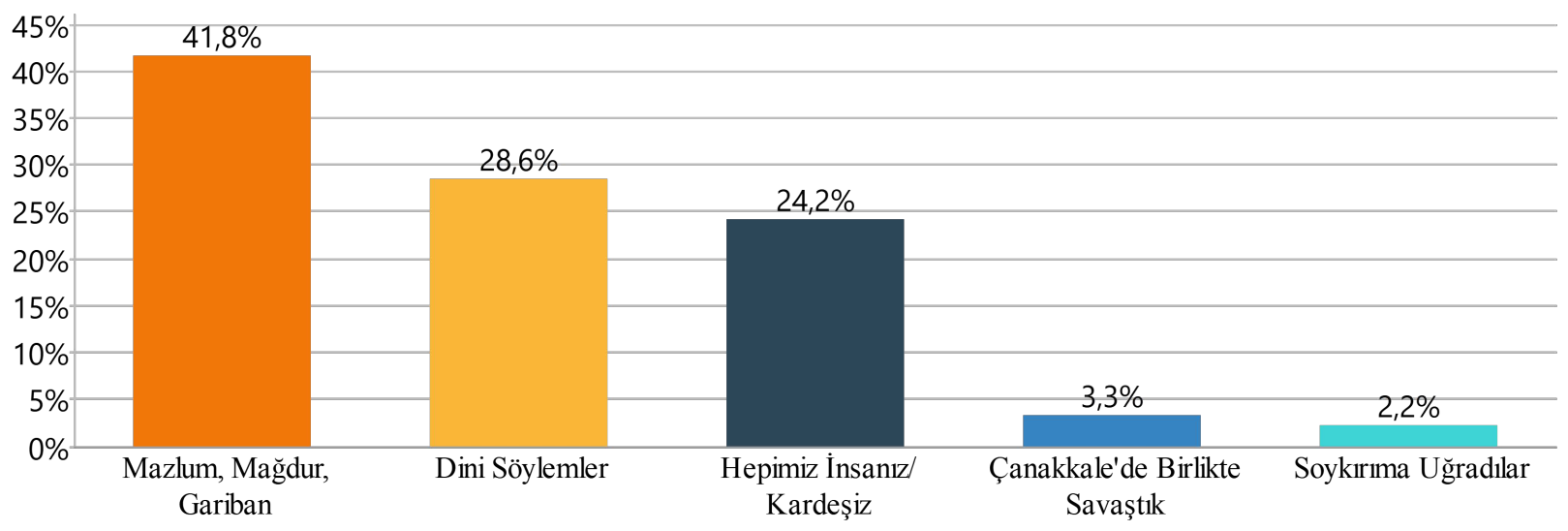

Şekil 8. Hoşgörü Söylemlerine Ait Alt Temaların Oranları

Nefret söylemleriyle kıyaslandığında çok daha düşük düzeyde kalsa da Suriyeli sığınmacılara yönelik olumlu yaklaşımların da yer aldığı görülmektedir. Suriyeli sı̆̆ınmacılara sempati duyanların ve/veya empatiyle yaklaşanlar en fazla mazlum, mă̆dur, gariban gibi ifadeler kullanmışlardır.

Suriyelilere yönelik empati ve sempati içeren ifadeler toplumunun hoşgörülü yönünü göstermektedir. Bu tür söylem ve ifadelere bakıldığında Suriyelileri istemeyen Türk vatandaşlarına yönelik eleştirilerin ağırlıklı olduğu görülmektedir. Nitekim bu tema altında yer alan alt temalar ile "Suriyelileri istemeyenlere eleştiri" ve "Suriyelileri ülkeye kabul gerekçeleri" alt temaların arasında ilişki bulunmaktadır. 
Sempati ve empati söylemlerinde bulunanlarda dikkat çeken bir başka husus ise Suriyelilere karşı birtakım eleştirilerinin de olmasıyla ilgilidir. Her ne kadar Suriyeli sığınmacılar mazlum, mağdur ve gariban olarak nitelendirilse de çok çocuk yapmaları eleştirilmiştir. Ayrıca Suriyeli sı̆̆ınmacılar nedeniyle kültürel değişim korkusu ve güvenlik korkusu da beslemektedirler. Türk toplumunun işsizliği de sempati ve empati söylemleri içeren ifadelerin bulunduğu gönderilerde dile getirilmiştir.

\subsubsection{Suçlamalar}

Suçlamalar teması altında yer alan alt temalar, Sosyal ilişkiler teması altında yer alan "Bir arada yaşamaya hoşnutsuzluk" alt teması içinde değerlendirilmeyen, eleştiriden ziyade Suriyelilere yönelik olumsuz ithamların yer aldı ğı ifadeleri içermektedir. Bu bağlamda Suriyelilere yönelik önyargı ifadelerinden ziyade kalıp yargı içeren ifadeler “Suçlamalar” teması altında değerlendirilmiştir.

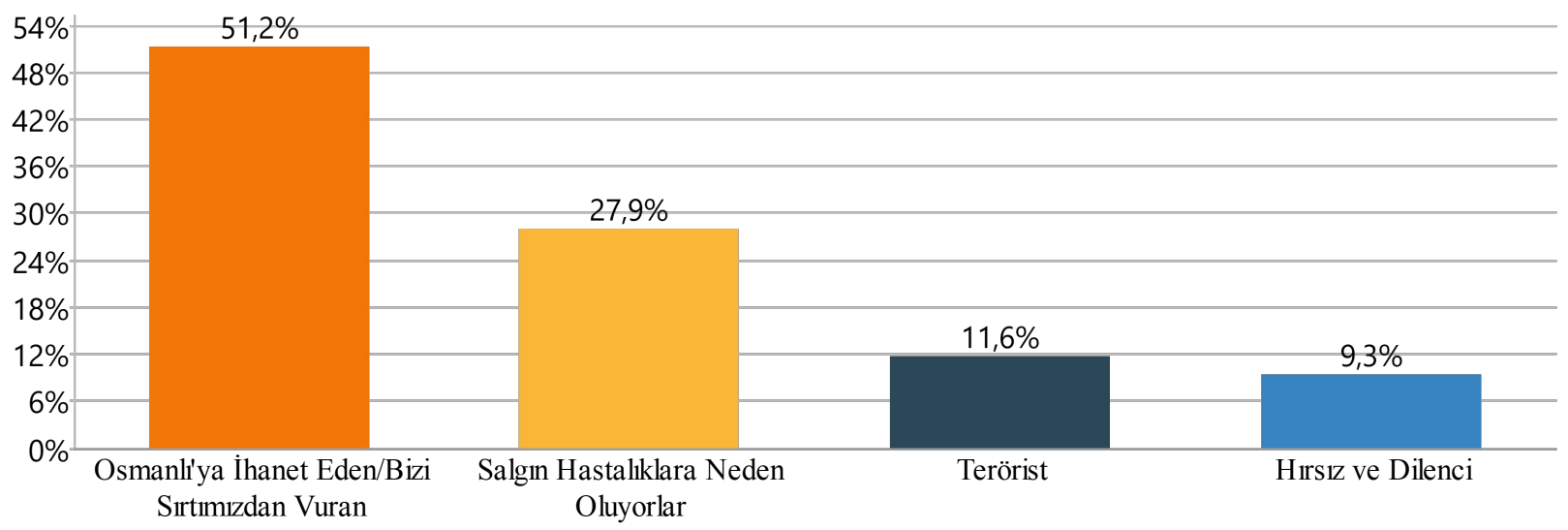

Şekil 9. Suçlamalar Temasına Ait Alt Temaların Oranları

Suriyelilere yönelik en fazla yapılan suçlama “Osmanlıya ihanet eden/Bizi sırtımızdan vuran” bir millet olarak görülmelerinden kaynaklanmaktadır. İkinci sırada "Suriyelilerin salgın hastalıklara neden olduğu” yönünde suçlama yer almaktadır. Bu ithamları "terörist”" ve "hırsız ve dilenci" ithamları takip etmektedir.

Sağlık bilimleri alanında yapılan çalışmalar göz önüne alındığında mevcut literatürde Suriyeli sı̆̆ınmacıların salgın hastalığa neden olduğuna yönelik bir tespit yer almamaktadır. Sadece iki çalışmada kızamık hastalığında 2013 yılında ciddi bir artışın yaşandığı fakat sonraki yıllarda aşı çalışmalarıyla kızamık salgınının önlendiği ve ayrıca kızamık salgınının Suriyelilerle ilişkili olup olmadığının belirsiz olduğu belirtilmiştir (Altındiş, 2013, s.64-67; Sezen, vd., 2018, s.122). Öte yandan Türkiye’de 11 Mart 2020 yılında ilk defa görülen Covid-19 virüsünün ardından “Suriyeli 40” ifadesi Twitter’ da gündem olmuştur. Bu tarihte söz 
konusu ifadenin gündem olmasının nedeni virüs nedeniyle Türk halkına yapılacak olan yardımların açıklanmasıyla ilgilidir. Suriyelilere şimdiye kadar 40 milyar dolar harcandığı halde virüs nedeniyle Türk vatandaşlarına yeterli yardımların yapılmadığı yönünde eleştiriler nedeniyle gündem oluşmuştur. Fakat bu tarihte yer alan ve ardından 28.04.2020 tarihinde Suriyeli bir gencin polis tarafından öldürülmesi nedeniyle tekrar gündem olan Suriyeli sı̆̆ınmacılar Covid-19 ile ilişkilendiren gönderi tespit edilememiştir. Bu durum pandemi sürecinde Suriyelilerin günah keçisi ilan edilmediklerini göstermektedir.

\subsubsection{Vatandaşlık}

Twitter'da yapılan yorumlar arasında vatandaşlık ile ilgili konulara da değinilmiş olmakla birlikte oldukça düşük düzeyde kalmıştır.

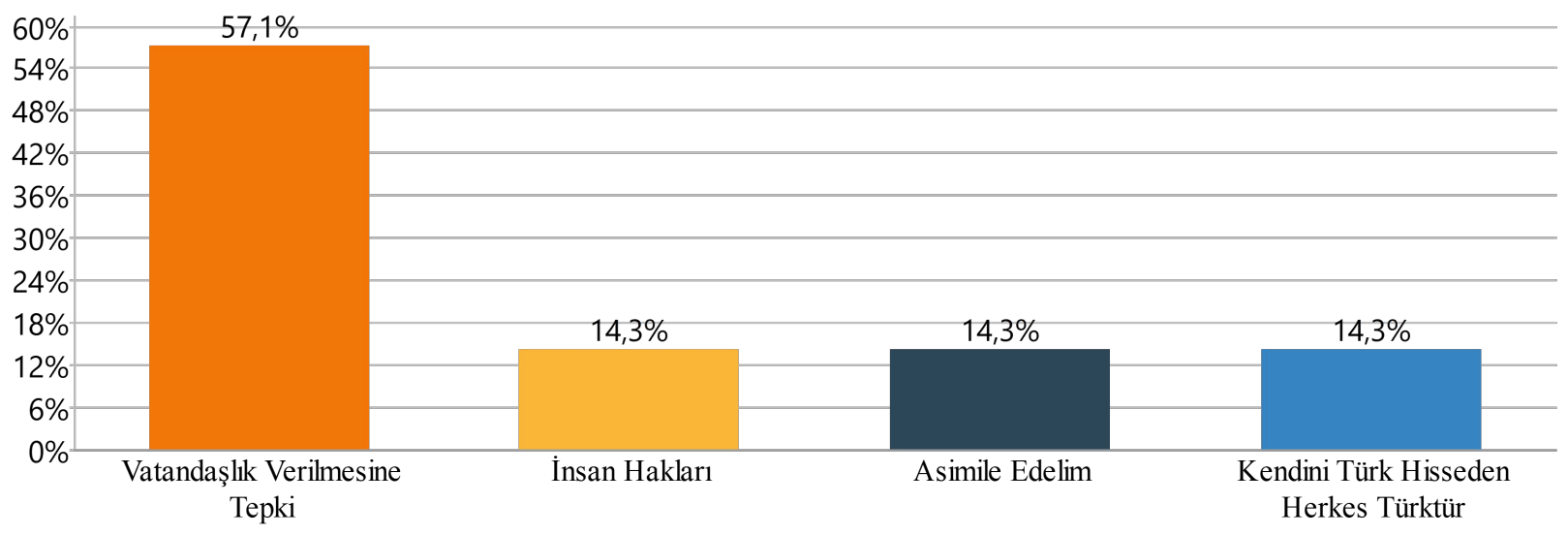

Şekil 10. Vatandaşlık Temasına Ait Alt Temaların Oranı

Vatandaşlık hususunda en fazla yorum Suriyelilere vatandaşlık verilmemesiyle ilgilidir. Daha düşük düzeyde ise "Sı̆̆ınmacı hakkı insan haklarıdır”, “Asimile edelim” ve "Kendini Türk hisseden herkes Türk'tür” ifadeleri yer almaktadır. Bu ifadelerde örtük şekilde vatandaşlığa kabul anlamına geldiği düşünülmektedir. Vatandaşlık ile ilgili söylemlerin düşük düzeyde kalmış olması, Türk toplumunun Suriyelere vatandaşlık verilmesiyle ilgili kaygılarının düşük olduğunu göstermektedir. Aynı zamanda “Suriyelileri kabul gerekçeleri” alt teması göz önünde bulundurulduğunda Türk vatandaşlarının Suriyelileri “misafir” olarak kabul etmekle birlikte vatandaşlık düzeyinde kabul etmediklerini göstermektedir.

\section{Sonuç}

Yoğun nüfuslu göçler kültürel çeşitliliğin artmasıyla birlikte yeni kültürel deneyimler ve yeni ekonomik 
fırsatlar sunabileceği gibi siyasi, sosyal, ekonomik ve güvenlikle ilgili sorunların ortaya çıkmasına neden olabilmektedir. Bu nedenle göçlerin olumsuz etkilerine yönelik önlemlerin alınması gereklidir, fakat göçlerle birlikte ortaya çıkan sorunların hızlı ve kolay çözümleri bulunmamaktadır. Her ülkenin kendine özgü sosyal koşullarının olduğu göz önünde bulundurulduğunda, her ülkenin göçün tetiklediği sorunları çözümü de kendi sosyal koşullarına uygun olması gerekmektedir. Bu bağlamda yaklaşık on yıldır geçici koruma statüsü altında Türkiye'de bulunun Suriyelilerle bir arada yaşama deneyimi edinmiş bulunun Türk toplumunun Suriyelilere yönelik alg1 ve görüşleri ileriye dönük politikaların belirlenmesi bakımından önem arz etmektedir.

Araştırmada kapsamında bir arada yaşama deneyimi bağlamında Türk toplumunun Suriyelilere yönelik alg1 ve görüşlerde hangi unsurların ön plana çıktığı ve genel olarak Suriyeli algı ve görüşlerini belirleyen unsurun çalışma hakkı ve ekonomi olup olmadığı araştırılmıştır. Araştırma bulgularından elde edilen sonuçlar ise şöyledir:

- Suriyelilerin Twitter'da 16 Ocak 2020 tarihinde gündem olma nedeni Suriyelilere İSKKUR aracıllğ iş verileceğine yönelik tam olarak gerçeği yansıtmayan çarpıtma bir haberdir. Yani ekonomi ve çalışma hakkıyla ilgili bir husustur. Buna rağmen Suriyelilere yönelik mevcut değerlendirmelerin oransal olarak sıralaması; "Sosyal ilişkiler", "Nefret söylemleri”, "Suriyelilerin kabul edilmesi veya edilmemesiyle ilgili gerekçeler”, "Çalışma hakkı”, “Siyasi söylemler”, "Ekonomi”, "Hoşgörü söylemleri”, "Suçlamalar" ve "Vatandaşlık” şeklinde farklı konuları kapsamaktadır. Bu durum, Suriyelilere yönelik rahatsızlığın ana kaynă̆ının Suriyelilerin ülke ekonomisi üzerine olumsuz etkisi ve Suriyelere iş verilmesine yönelik duyulan rahatsızlıkla tam olarak ilgisinin olmadığını göstermektedir. Elde edilen bulgulara göre mevcut algı ve görüşlerin nedeni, Suriyelilerin Türk toplumu için istenmeyen birer yabancı olarak görülmesinden, iç gruba dahil olmaları henüz mümkün olmayan ötekiler olarak kabul edilmelerinden kaynaklanmaktadır. Bu bağlamda Suriyelilerin bir öteki olarak temsilinin ötekileştirmenin işlevleri arasından "Yansıtmayla rahatlama ya da kimlik yüceltme işlevi” ve "Sosyal düzeni koruma işlevi” ile ilişkili olduğu söylenebilir.

- Türk toplumu Suriyeli sığınmacılara yönelik iki farklı görüşe ayrılmaktadır ve bu ayrışma nedeniyle karşılıklı olarak birbirlerine eleştiriler yöneltmişlerdir. Ülkede Suriyeli sı̆̆ınmacıları istemeyen kesim genel olarak etnik ve ulus kimliğine vurgu yaparken Suriyelilere hoşgörüyle bakanlar ise Suriyelileri istemeyenlere karşı dini kimlik ekseninde eleştirilerde bulunmuşlardır. Bu durum Suriyeli algısını belirleyen ana unsurun neden çalışma hakkı ve ekonomi olmadığını izah etmektedir. Ekonomi ve çalışma hakkı dâhil olmak üzere Suriyelilere yönelik algı ve görüşler etnik, dini ve ulus 
kimlik ekseninde şekillenmektedir.

- Suriyelilere yönelik suçlamalardan biri salgın hastalıklara neden oldukları yönündedir. Bu durum Suriyelilerin bir öteki olarak görülmelerinden kaynaklıdır. Fakat çalışma kapsamında 17 Mart ve 28 Nisan tarihinde yer alan tweetlerde yapılan araştırmada Suriyeli sığınmacıların Covid-19 virüsü nedeniyle suçlanmadıkları belirlenmiştir.

- Verilerin analizi boyunca sıkça nefret söylemi unsurlarına rastlanılmış olmakla birlikte Suriyeli sı̆̆ınmacılara karşı hoşgörü söylemleri de yer almaktadır. Bu kategori altında yer alan söylemleri kullananların ülkede Suriyelilerin mevcudiyetini destekledikleri görülmekle birlikte Suriyelilere karşı tamamen olumlu görüşlere sahip oldukları söylenemez. Örneğin bu kategoride yer alan ifadeler Suriyelileri çok çocuk yapmaları nedeniyle eleştirmekte, güvenlik ve kültürel değişim korkusu gibi kaygılar da yaşamakta ayrıca Türk toplumunun işsizliğinden de bahsetmektedirler.

Mevcut veriler 1şığında genel bir değerlendirme olarak denilebilir ki Türk toplumu için Suriyeli sığgınmacılarla bir arada yaşama deneyimlerine rağmen henüz bir bütünleşme mümkün görünmemekte, çoğu kişi için yaşam düzenine kafa tutan “yabancılar” olarak algılandığı görülmektedirler.

Bir diğer önemli husus ise sı̆̆ınmacılar hakkında yapılan yalan ve çarpıtılmış haberlerin sosyal medyada hızlıca ülke gündemine girmesidir. Bu haberler sığınmacılara yönelik olumsuz algı ve görüşlerin yayılmasına neden olması nedeniyle yalan haberlere karşı etkin mücadele verilmesi gereklidir.

Suriye krizi ilk çıktığında Türk kamuoyunda ve akademiasında, gelen mültecilerin İslam dinine mensup olmalarının onların adaptasyon ve uyumlarına olumlu katkı sağlayacağı fikri öne çıkmıştı. Oysaki kriz üzerinden on yıl geçtikten sonra İslam faktörünün de bir yere kadar işlev görebildiği, hatta dindar ve muhafazakâr kesimde bile yeteri derecede dahil edici bir fenomen olarak değer bulmadı̆̆ı görülmektedir. Bu konuda uyumun karşılıklı yönüne işaret etmek ve bir devlet refleksi içinde konuyu ele almak gerekmektedir. Bu konuda klasik göçmen ülkeleri iyi bir model oluşturabilir

\section{Kaynaklar}

Akerlof, G. A., Kranton, R. E. (2016). Kimlik İktisadı, Kimliklerimiz, İsimizi, Ücretimizi ve Refahımızı Nasıl Şekillendiriyor? Can Madenci (Çev.). Ankara: Efil Yayınevi.

Aldemir, A. (2020). Kötülüŭün sıradanlığg ve sosyal medya: Twitter'da Suriyeli mülteciler örneği. Dumlupınar Üniversitesi Sosyal Bilimler Dergisi, 66, 200-219. 
Allport, G. W. (2016). Önyargının oğası. Nur Nirven (Çev.). Sakarya: Sakarya Üniversitesi Kültür Yayınları.

Altındiş, M. (2013). Türkiye'deki mülteciler, salgın hastalıklar ve koruma. Sağlık dü̈süncesi ve Tıp Kültürü Dergisi, 28, 64-67.

Aslan, Ö. (2001). Hoşgörü ve tolerans kavramlarına etimolojik açıdan analitik bir yaklaşım. Cumhuriyet Üniversitesi Illahiyat Fakültesi Dergisi, 5(2), 357-380.

Arslantürk, G. (2020). Sosyal medyadaki göçmen karşııı tutumların bütünleşik tehdit kuramı çerçevesinden incelenmesi. Psikoloji Araştırmaları, 1(1), 06-16.

Aydın, S., Oğuz, H. Ş. (2015). “Şeytanlaştırılan Gruplar: Ulus-Devlet Pratiğinde Ötekileştirmenin ve Etnik Kurtulmanın Mültecilik Bağlamında Zihinsel İnşası”. İ.Parlak (Ed.), Öteki’nin Var Olma Sancısı Türk Politik Kültüründe Şeytanlaşttrma Eğilimleri. Bursa: Dora Yayıncılık.

Ayrımcı Sözlük, Araplara Karşı Ayrımcı Deyiş, Deyim ve Atasözleri, www.ayrimcisozluk.blogspot.com, (Erişim Tarihi: 22.08.2021).

Baudrillard, J. (2015). Şeytana Satılan Ruh ya da Kötülü̆ğ̈̈n Egemenliği. 3. Baskı, Oğuz Adanır (Çev.). Ankara: Doğu Batı Yayınları.

Bauman, Z. (2003). Modernlik ve Müphemlik. İsmail Türkmen (Çev.). İstanbul: Ayrıntı Yayınları.

Bauman, Z. (2006). Sosyolojik Düşünmek. 5. Baskı, Abdullah Yılmaz (Çev.), İstanbul: Ayrıntı Yayınları.

Bauman, Z. (2011). Postmodern Etik. 2. Baskı, Abdullah Yılmaz (Çev.). İstanbul: Ayrıntı Yayınları.

Bauman, Z. (2019). Kapımızdaki Yabancılar. 2. Baskı, Emre Barca (Çev.). İstanbul: Ayrıntı Yayınları.

Bayram, P. (2020). Sosyal medyada Suriyeli mülteci krizine ilişkin konum alışlar: Türkiye'deki politik gençlik üzerinden bir analiz. Balıkesir University The Journal of Social Sciences Institute, 23(44), 1213-1251.

Bhawuk, D. P. S., Brislin, R. (1992). The Measurement of intercultural sensitivity using the concepts of individualism and collectivism. International Journal of Intercultural Relations, 16, 413-436.

Bilgin, N. (2007). Kimlik İnşası. Ankara: Aşina Kitaplar. 
Castles, S., Miller, M. J. (2008). Göçler Çă̆̆ Modern Dünyada Uluslararası Göç Hareketleri, Bülent Uğur Bal, İbrahim Akbulut (Çev.). İstanbul: İstanbul Bilgi Üniversitesi.

Connolly, W. E. (1995). Kimlik ve Farklılık Siyasetin Açmazlarına Dair Demokratik Çözüm Önerileri. Ferma Lekesizalın (Çev.). İstanbul: Ayrıntı Yayınları.

Erdoğan, M. M. (2020). Suriyeli Barometresi 2019. Ankara: Orion Kitabevi.

Gasset, J. L. (2003). Insan ve “Herkes”. 4. Baskı, Nuriye Gül Iş1k (Çev.), İstanbul: Metis.

Güvenç, B. (1995). Türk Kimliği-Kültür Tarihinin Kaynakları. 3. Baskı, İstanbul: Remzi Kitabevi.

Gölcü, A., Dağlı, A. N. (2017). Haber söyleminde ‘Öteki’yi aramak: Suriyeli mülteciler örneği. Akdeniz Illetişim, 28, 11-38.

Huntington, S. P. (2004). Biz Kimiz? Amerika'nın Ulusal Kimlik Anlayışı, Aytül Özer (Çev.) İstanbul: CSA Global.

İnce, H. O. (2011). Almanya'da farklı olmak: entegrasyon ve hoşgörü kavramına eleştirel bir bakış. Bilig Dergisi, 58, 173-202.

İşçi, D., Uludă̆ E. (2019). Sosyal medyada Suriyeliler algısı: Youtube sokak röportajları üzerine bir inceleme. Ulisa: Uluslararası Çalışmalar Dergisi, 3(1), 1-24.

Kardeş, S., Banko, Ç., Akman, B. (2017). Sosyal medyada Suriyeli sı̆̆ınmacılara yönelik algı: bir sözlük değerlendirmesi. Göç Dergisi, 4(2), 185-200.

Kaya, A. (2015). Euro-Türkler, kuşaklararası farklılıklar, İslam ve entegrasyon tartışmaları. Göç Araştırmaları Dergisi, 1(1), 44-79.

Keyman, E. F. (1996). "Farklılı̆̆a Direnmek: Uluslararası İlişki Kuramında Öteki Sorunu, Oryantalizm, Hegemonya ve Kültürel Fark. Fuat Keyman, M. Mutman, M. Yeğenoğlu (Der.), İstanbul: İletişim Yayınları.

Kırıkçı, A. C. (2017). Sosyal Bilgiler ve Kapsamındaki Ders Kitaplarında Doğu-Batı Bağlamında Öteki: (1928-2017). Marmara Üniversitesi Eğitim bilimleri Enstitüsü İlköğretim Anabilim Dalı Sosyal Bilgiler Öğretmenliği Bilim Dalı.

Kierkegaard, S. (2013). Kaygı Kavramı. 7. Baskı, Türker Armaner (Çev.), İstanbul: Türkiye İş Bankası Kültür Yayınları. 
Kurt, G. (2019). Yeni medyada nefret söylemi: Youtube'da Suriyeli mültecilere karşı üretilen nefret söylemi üzerine bir araştırma. The Journal of International Lingual, Social and Educational Sciences, 5(1), 1-20.

Kuş, O. (2016). Dijital nefret söylemini anlamak: Suriyeli mülteci krizi örnek olayı bağlamında BBC World Service Facebook sayfasına gelen yorumların metin madenciliği tekniği ile analizi. Ístanbul Üniversitesi İletişim Fakültesi Dergisi, 51, 97-121.

Mbembe, A. (2019). Zenci Aklın Eleştirisi. Özge Arasan Simon, Volkan Çavdar (Çev.). İstanbul: İletişim Yayınlar1.

Mlodinow, L. (2013). Subliminal Bilinçdışınız Davranışlarınızı Nasıl Yönetir? 15. Baskı, Nuray Önoğlu (Çev.), İstanbul: Okyan Us.

Nahya, N. (2011). İmgeler ve ötekileştirme: Cadılar, Yerliler ve Avrupalılar. Atılım Sosyal Bilimler Dergisi, $1(1), 27-38$.

Öksüz, M. (2020). Siber mekânda Suriyeli mültecilere yönelik faşizm halleri: Faşekşist. Coğrafi Bilimler Dergisi, 18(2), 246-275.

Özdemir, F., Öner Özkan, B. (2016). Türkiye'de sosyal medya kullanıcılarının Suriyeli mültecilere ilişkin sosyal temsilleri. Nesne Psikoloji Dergisi (NPD). 4(8), 227-244.

Patton, M. Q. (2014). Nitel Araştırma ve Değerlendirme Yöntemleri. Mesut Bütün, Selçuk Beşir Demir (Çev.). Ankara: Pegem Akademi.

Saldana, J. (2019). Nitel Araştırmacılar İçin Kodlama El Kitabı. Aysel Tüfekci Akcan, Süleyman Nihat Şad (Çev.). Ankara: Pegem Akademi.

Sayımer, İ., Rabenda Derman, M. (2017). Syrian Refugees as victims of fear and danger discourse in social media: a Youtube analysis. Global Media Journal TR Edition, 8(15), 384-403.

Schnapper, D. (1995). Yurttaşlar Cemaati Modern Ulus Fikrine Dair. Özlem Okur (Çev.). İstanbul: Kesit.

Schnapper, D. (2005). Sosyoloji Düşüncesinin Özünde Öteki ile İlişki. Ayşegül Sönmezay (Çev.). İstanbul: İstanbul Bilgi Üniversitesi Yayınları.

Sezen, İ., Turan, M., Kaya, A. A. (2018). Türkiye'deki Suriyeli misafirler ve ilişkilendirilen bulaşıcı hastalıklar. Gümüşhane Üniversitesi Să̆llk Bilimleri Dergisi, 7(4), 119-127. 
Sherif, M. (1988). The Robbers Cave Experiment: Intergroup Conflict and Cooperation. Wesleyan University Press.

Sorokin, P. A (1997). Bir Bunalım Çă̆ında Toplum Felsefesi. 2. Baskı, Mete Tunçay (Çev.), İstanbul: Göçebe Yayınları.

Tarhan, N. (2013). Toplum Psikolojisi Sosyal Şizofreniden Toplumsal Empatiye. 6. Baskı, İstanbul: Timaş Yayınları.

Taşdelen, B. (2020). Twitter'da Suriyeli mültecilere karşı çevrimiçi nefret söylemi: \#suriyelileriistemiyoruz. Gümüşhane Üniversitesi Sosyal Bilimler Enstitüsü Elektronik Dergisi, 11(2), 562-575.

Tekeli, İ. (1998). Tarihyazımı Üzerine Düşünmek. Ankara: Dost Kitabevi.

Uzunçarşılı Soydaş, A. (2010). Kültürlerarası İletişim Farklı Kültürel Ortamlarda Çalışma ve İletişim. İstanbul: Parşömen.

Watt-Smith, T. (2019). Duygular Sözlüğü. 3. Bask1, Hale Şirin (Çev.). İstanbul: Kolektif Kitap.

Weber, A. (2009). Nefret Söylemi El Kitabı. Metin Çulhaoğlu (Çev.). Strazburg: Avrupa Konseyi Yayınları.

Volkan, V. D. (2017). Körü Körüne İnanç Kriz ve Terör Dönemlerinde Geniş Gruplar ve Liderleri. Özgür Karaçam (Çev.). İstanbul: Asi Kitap.

Van der Veer, K., Ommundsen, R., Yakushko, O., Higler, L., Woelders, S., Hagen, K. A. (2013). Pyschometrically and qualitatively validating a cross-national cumulative measure of fear-based Xenophobia. Quality \& Quantitiy, 47(3), 1429-1444.

Yazıc1, T. (2016). Yeni medyanın nefret dili Suriyeli mültecilerle ilgili Ekşi Sözlük örneği. Global Media Journal TR Edition, 7(13), 115-136.

Yıldırım, S., Tekdemir Yurttaş, G. (2016). Türkiye'deki katılımcı sözlüklerde Suriyeli sı̆̆ınmacıların sosyal inşası: sosyal medya ve açıklayıcı repertuarlar. Middle East Journal of Refugee Studies, 1(1), 77-122.

Yıldız, E. (2018). Twitter'da ve çevrimiçi bir gazetede yer alan nefret söylemlerinin karşılaştırılması: Suriyeli mülteciler örneği. Uluslararası Toplum Araştırmaları Dergisi, 9(16), 760-793. 


\section{Makale Bilgi Formu}

Yazar(lar)ın Katkıları: Makaleye tüm yazarlar eş katkı sağlamıştır.

Çıkar Çatışması Bildirimi: Yazar tarafından potansiyel çıkar çatışması bildirilmemiştir.

Destek/Destekleyen Kuruluşlar: Bu araştırma için herhangi bir kamu kuruluşundan, özel veya kar amacı gütmeyen sektörlerden hibe alınmamıştır.

Etik Onay ve Katılıme Rızası: “Suriyeli Sı ̆̆ınmacılarla Birlikte Yaşama Deneyimi Bağlamında Alg1 ve Görüşler: Twitter Üzerinden Suriyelilerin Sosyal Temsili” başlıklı çalışmanın yazım sürecinde bilimsel, etik ve alıntı kurallarına uyulmuş; toplanan veriler üzerinde herhangi bir tahrifat yapılmamış, karşılaşılacak tüm etik ihlallerde "Universal Jounal of History and Culture" hiçbir sorumluluğu olmayıp, tüm sorumluluk yazarlara aittir. 